\title{
Article \\ Highly Diastereoselective Chelation-Controlled 1,3-anti-Allylation of (S)-3-(Methoxymethyl)hexanal Enabled by Hydrate of Scandium Triflate
}

\author{
Uladzimir S. Masiuk ${ }^{1,2}$, Iryna V. Mineyeva ${ }^{1, *}$ and Dzmitry G. Kananovich $2, * \mathbb{D}$ \\ 1 Department of Organic Chemistry, Belarusian State University, Leningradskaya 14, 220050 Minsk, Belarus; \\ masiukvs@yandex.ru \\ 2 Department of Chemistry and Biotechnology, School of Science, Tallinn University of Technology, \\ Akadeemia Tee 15, 12618 Tallinn, Estonia \\ * Correspondence: i.mineyeva@yandex.ru (I.V.M.); dzmitry.kananovich@taltech.ee (D.G.K.)
}

check for

updates

Citation: Masiuk, U.S.; Mineyeva,

I.V.; Kananovich, D.G. Highly

Diastereoselective

Chelation-Controlled

1,3-anti-Allylation of

(S)-3-(Methoxymethyl)hexanal

Enabled by Hydrate of Scandium

Triflate. Symmetry 2021, 13, 470.

https://doi.org/10.3390/sym13030470

Academic Editor: Eugenijus Butkus

Received: 19 February 2021

Accepted: 11 March 2021

Published: 13 March 2021

Publisher's Note: MDPI stays neutral with regard to jurisdictional claims in published maps and institutional affiliations.

Copyright: (c) 2021 by the authors. Licensee MDPI, Basel, Switzerland. This article is an open access article distributed under the terms and conditions of the Creative Commons Attribution (CC BY) license (https:/ / creativecommons.org/licenses/by/ $4.0 /)$.

\begin{abstract}
En route to the total synthesis of (+)-Neopeltolide, we explored Lewis acid-assisted diastereoselective allylation of MOM-protected 3-hydroxylhexanal with $\beta$-(2,2-diethoxyethyl)-substituted (allyl)tributylstannane. The hydrated form of scandium triflate was found to be essential for attaining high 1,3-anti-diastereoselectivity (d.r. 94:6), while the use of anhydrous catalyst resulted in a modest diastereocontrol (d.r. 76:24). The preferred 1,3-anti-selectivity in this transformation can be rationalized in the framework of the Reetz chelate model of asymmetric induction. The 1,3-anticonfiguration of the product was confirmed by its conversion into the known $C^{7}-C^{16}$ building block of (+)-Neopeltolide. We also report an improved protocol for the synthesis of $\beta$-(2,2-diethoxyethyl)substituted (allyl)tributylstannane, which can be utilized as a cost-efficient bipolar isoprenoid-type $\mathrm{C}_{5}$-building block in the synthesis of natural compounds.
\end{abstract}

Keywords: Reetz-Keck-type allylation; stannylation; Lewis acids; organotin compounds; $\beta$ oxyaldehydes; scandium triflate; chelation control; asymmetric synthesis; asymmetric induction

\section{Introduction}

Stereoselective allylation of carbonyl compounds allows to assemble a carbon-carbon bond along with installation of a new stereocenter [1-4]. The produced homoallylic alcohols provide multiple opportunities for the subsequent modifications and therefore are widely used in the target-oriented synthesis of natural and bioactive compounds [2-5].

In the event of asymmetric induction, the transfer of chirality to the newly formed stereocenters is typically enabled either by a chiral catalyst/reagent or a chiral substrate itself. The latter case commonly occurs in the multistep synthesis of natural products and could require fine tuning of the reaction parameters to attain a high level of stereocontrol. In that sense, diastereoselective allylation of chiral $\alpha$ - and $\beta$-oxysubstituted aldehydes is advantageous [4,6-14] since its stereochemical outcome can be usually [15] predicted in the framework of Felkin-Ahn [16-21], Cornforth-Evans [16,17,22-24], or Cram [16,17,25-27] and Reetz chelation $[16,17,28-30]$ models. The Reetz model is valid in the case of stereoselective addition of allylstannanes to $\beta$-oxysubstituted aldehydes, where the high 1,3anti-selectivity is commonly achieved due to the formation of a chelate complex between a Lewis acid catalyst and the aldehyde substrate [31,32]. On the other hand, the successful chelation control takes place only for a limited set of known $\beta$-hydroxy-protecting groups and Lewis acids [7-14,31-35]. Moreover, rather ordinary unsubstituted allylic organotin reagents are commonly employed in these transformations, with only rare examples of $\beta$-functionalized analogues [8,14,36-39]. The development of more complex allyl-transfer reagents is appealing in view of their evidently high synthetic value [40-48].

During the implementation of our research programs devoted to the synthesis of natural and bioactive compounds from cyclopropanols [49-52] and cyclopropanol-derived build- 
ing blocks [53-56], we expected to develop a bifunctional allylation reagent A (Scheme 1) based on metalation of easily available allyl bromide $\mathbf{1}$ [53]. The reagent $\mathbf{A}$ can act as a synthetic equivalent of a bipolar isopentane synthon, as it was previously demonstrated by the synthesis of retinoid compounds via the Barbier-type chemistry [53,56]. We envisioned that besides the assembly of polyene scaffolds, organometallic derivatives of $\mathbf{1}$, especially its organotin derivative 2 , could also be suitable for the stereoselective allylation of carbonyl compounds and therefore applied in the asymmetric synthesis of natural products. Our preliminary tests revealed that organotin compound 2 [57], along with its carboxymethyl analogue [54,55], are suitable for highly enantioselective Keck allylations. However, the substrate-controlled stereoselective coupling of $\mathbf{2}$ with oxy-functionalized aldehydes has not been examined. Moreover, we required to develop an expedient synthetic protocol for the preparation of $\mathbf{2}$ in multigram amount. As a result of our endeavors, here we report a convenient and cost-efficient procedure for multigram preparation of 2, and its application in the Lewis acid-mediated diastereoselective 1,3-anti-allylation of (S)-3-(methoxymethyl)hexanal 3. The stereochemical outcome of the reaction was further validated by the synthesis of known $C^{7}-C^{16}$ bulding block of (+)-Neopeltolide [55], containing three stereocenters.
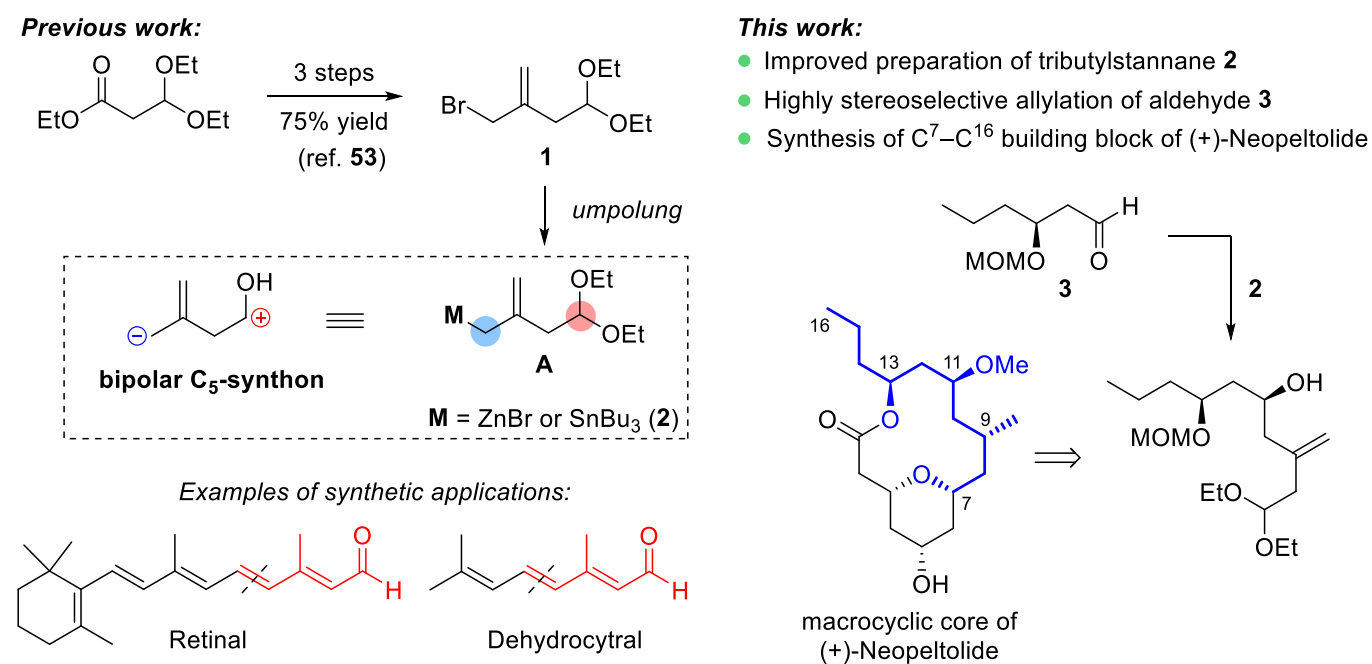

Scheme 1. Preparation of a bifunctional allylation reagent $\mathbf{A}$ and outline of the current work.

\section{Results and Discussion}

\subsection{Improved Protocol for the Preparation of Functionalized (Allyl)Tributylstannane 2}

Multistep synthesis commonly requires substantial quantity of starting materials at the initial stages. Therefore, a facile and cost-efficient access to large quantities of $\mathbf{2}$ was of primary importance. Using the advantages of cyclopropanol chemistry [58,59], allyl bromide 1 was readily prepared in multigram amounts and 94\% overall yield from cheap and easily available ethyl 3,3-diethoxypropionate (4) via the consequent Kulinkovich cyclopropanation [60], mesylation, and $\mathrm{MgBr}_{2}$-mediated cyclopropyl-allyl rearrangement steps (Scheme 2) [53,61-63]. The reaction sequence was flawlessly performed in a single run starting from $20 \mathrm{~g}$ of ester 4 (see the experimental part). No purification was required for the cyclopropane intermediates 5 and $\mathbf{6}$, which were obtained in nearly quantitative yields.

The previously reported method [57] for the preparation of organotin compound 2 via Barbier-type coupling of $\mathbf{1}$ and $\mathrm{Bu}_{3} \mathrm{SnCl}$ was found impractical for multigram preparation. Following the previously reported approach, organotin compound 2 was obtained in a moderate $66 \%$ yield due to accompanying homo-coupling of $\mathbf{1}$ leading to 7 . The purity of 2 was also unsatisfactory because of the contaminant inorganic salts. Incompatibility of acid-sensitive 2 with silica gel made its chromatographic purification impossible [57]. 


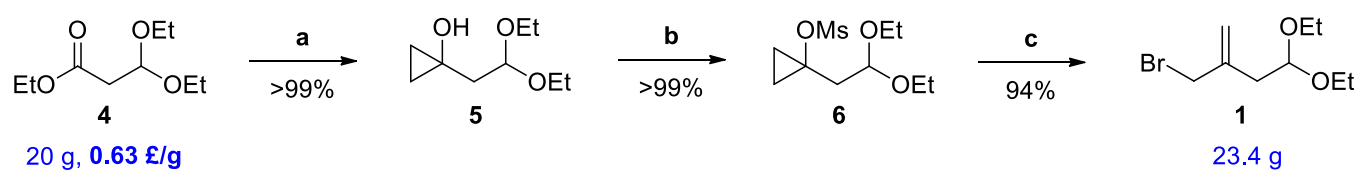

Reagents and conditions: (a) $\mathrm{EtMgBr}, \mathrm{Ti}(\mathrm{O} i-\mathrm{Pr})_{4}(20 \mathrm{~mol} \%)$, THF, r.t.; (b) $\mathrm{MsCl}, \mathrm{DIPEA}, \mathrm{Et}_{2} \mathrm{O}, 0^{\circ} \mathrm{C} ;(\mathbf{c}) \mathrm{MgBr}_{2}$, $\mathrm{Et}_{2} \mathrm{O}, \mathrm{r} . \mathrm{t}$.

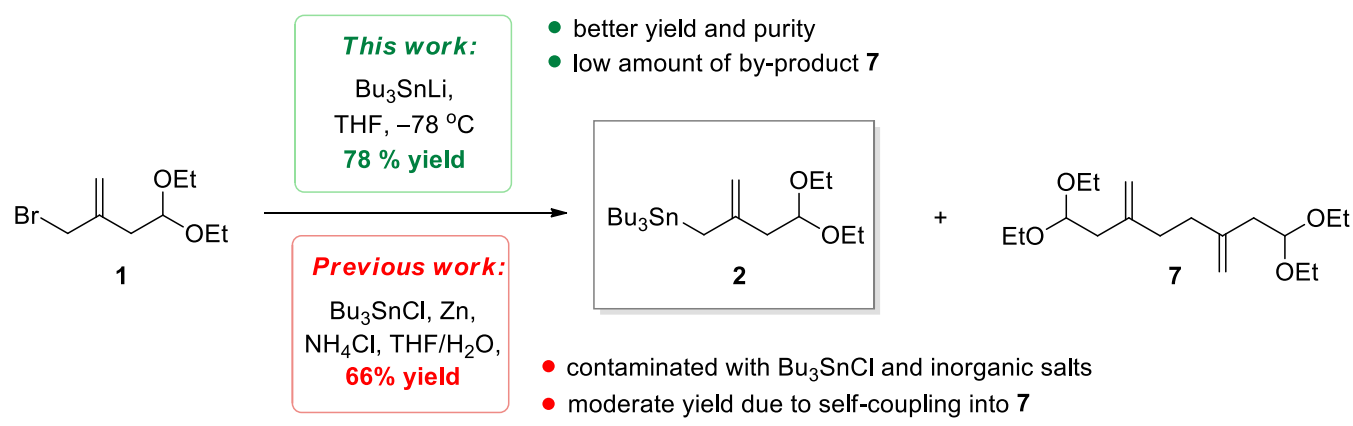

Scheme 2. Synthesis of allyl bromide 1 and its conversion into organotin derivative 2.

Therefore, we tested an alternative procedure of halogen substitution in $\mathbf{1}$ with $\mathrm{Bu}_{3} \mathrm{SnLi}$ (Scheme 2) [14]. To our delight, the new approach delivered the target organotin compound 2 in affordable 78\% yield and noticeably better purity. According to ${ }^{1} \mathrm{H}$ NMR analysis, the content of homo-coupled product 7 was reduced to $8 \mathrm{~mol} \%$, along with the presence of $15 \mathrm{~mol} . \%$ of $\left(\mathrm{Bu}_{3} \mathrm{Sn}\right)_{2}$ dimer. These impurities do not interfere the reactivity of 2 and can be removed after the performing the allylation reaction. The same transformation was also convenient for multigram preparation (up to $7 \mathrm{~g}$ in a single run, see the experimental part). Hence, high yields and utilization of cheap chemicals have provided a convenient, scalable, and cost-effective access to $\mathbf{1}$ and $\mathbf{2}$ in the sufficient amounts.

\subsection{Diastereoselective Allylation of Aldehyde $\mathbf{3}$ with (Allyl)Tributylstannane $\mathbf{2}$}

While examining the potential routes towards the synthesis of (+)-Neopeltolide and its analogues [64-66], we attempted to perform the stereoselective allylation of MOMprotected 3-hydroxylhexanal 3 with (allyl)tributylstannane 2 . The aldehyde 3 (ee > 99\%) was prepared by following the known procedure [55] (see the Supplementary Materials). Initially, we planned to apply the venerable Keck asymmetric allylation, by using a catalytic system based on titanium tetraisopropoxide and a chiral BINOL ligand [57,67-69]. Although being a well-developed approach, the Keck reaction has several restrictions, such as allylation of unsaturated or sterically hindered aldehydes [46,67-70]. Moreover, the presence of multiple oxygen-containing functionalities in both $\mathbf{2}$ and $\mathbf{3}$ could interfere the reaction outcome due to the highly oxophilic nature of the titanium catalyst. In our hands, allylation of $\mathbf{3}$ with $\mathbf{2}$ by following the Keck reaction protocol has led to only trace amounts of the desired homoallylic alcohol 8 (Scheme 3) after an exhausting search for the optimal reaction conditions and even in the presence of trifluoroacetic acid $[67,69]$ or $\mathrm{B}(\mathrm{OMe})_{3}[71]$ as activating additives (Table 1, entry 1 ).
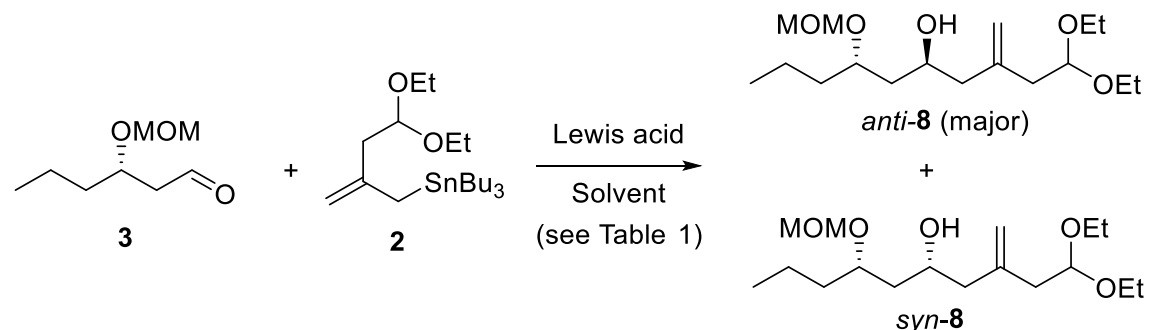

Scheme 3. Diastereoslective allylation aldehyde 3 with (allyl)tributylstannane 2. 
Table 1. Allylation of aldehyde 3 with allylstannane 2 promoted by Lewis acids. ${ }^{\text {a }}$

\begin{tabular}{|c|c|c|c|c|c|c|}
\hline Entry & Lewis Acid & Solvent & Time, $\mathrm{h}$ & $\mathrm{T},{ }^{\circ} \mathrm{C}$ & Conv. $\%$ & $\underset{\text { anti/syn }}{\text { d.r. }}$ \\
\hline 1 & $\operatorname{Ti}((S)-B I N O L)_{2}$ & $\mathrm{CH}_{2} \mathrm{Cl}_{2}$ & 120 & -20 & trace & - \\
\hline 2 & $\mathrm{TiCl}_{4}$ & $\mathrm{CH}_{2} \mathrm{Cl}_{2}$ & 1 & -78 & $-{ }^{c}$ & - \\
\hline 3 & $\mathrm{SnCl}_{4}$ & $\mathrm{CH}_{2} \mathrm{Cl}_{2}$ & 1 & -78 & $-{ }^{c}$ & - \\
\hline 4 & $\mathrm{TiCl}(\mathrm{O} i-\mathrm{Pr})_{3}$ & $\mathrm{CH}_{2} \mathrm{Cl}_{2}$ & 15 & -20 & \multirow{2}{*}{\multicolumn{2}{|c|}{$\begin{array}{l}\text { no reaction } \\
\text { no reaction }\end{array}$}} \\
\hline 5 & $\mathrm{Cp}_{2} \mathrm{TiCl}_{2}$ & $\mathrm{CH}_{2} \mathrm{Cl}_{2}$ & 15 & -20 & & \\
\hline 6 & $\mathrm{MgBr}_{2} \cdot \mathrm{Et}_{2} \mathrm{O}^{\mathrm{d}}$ & $\mathrm{CH}_{2} \mathrm{Cl}_{2}$ & 5 & -78 & 72 & $76: 24$ \\
\hline 7 & $\mathrm{ZnCl}_{2} \cdot \mathrm{Et}_{2} \mathrm{O}^{\mathrm{d}}$ & $\mathrm{CH}_{2} \mathrm{Cl}_{2}$ & 15 & -20 & 100 & $60: 40$ \\
\hline 8 & $\mathrm{ZrCl}_{4} \mathrm{~d}$ & $\mathrm{CH}_{2} \mathrm{Cl}_{2}$ & 1 & -60 & 78 & $73: 27$ \\
\hline 9 & $\mathrm{Sc}(\mathrm{OTf})_{3}$, old batch & $\mathrm{CH}_{2} \mathrm{Cl}_{2}$ & 4 & -25 & 65 & $84: 16$ \\
\hline 10 & $\mathrm{Sc}(\mathrm{OTf})_{3}$, old batch & toluene & 4 & -25 & 86 & $88: 12$ \\
\hline 11 & $\operatorname{In}(\mathrm{OTf})_{3}$ & toluene & 5 & -70 & 48 & $75: 25$ \\
\hline 12 & $\mathrm{Y}(\mathrm{OTf})_{3}$ & toluene & 2 & -20 & 45 & $55: 45$ \\
\hline 13 & $\mathrm{Hf}(\mathrm{OTf})_{4}$ & toluene & 4 & +20 & 28 & $65: 35$ \\
\hline 14 & $\mathrm{Sc}(\mathrm{OTf})_{3}$, fresh batch & toluene & 5 & -70 & 60 & $76: 24^{\mathrm{e}}$ \\
\hline 15 & $\mathrm{Sc}(\mathrm{OTf})_{3}+\mathrm{H}_{2} \mathrm{O}$ & toluene & 2 & -25 & 65 & $83: 14$ \\
\hline 16 & $\mathrm{Sc}(\mathrm{OTf})_{3}+2 \mathrm{H}_{2} \mathrm{O}$ & toluene & 4 & -25 & 72 & $88: 12$ \\
\hline 17 & $\mathrm{Sc}(\mathrm{OTf})_{3}+2 \mathrm{H}_{2} \mathrm{O}$ & toluene $/ \mathrm{Et}_{2} \mathrm{O}$ & 4 & -70 & 78 & $91: 9$ \\
\hline 18 & $\mathrm{Sc}(\mathrm{OTf})_{3}+2 \mathrm{H}_{2} \mathrm{O}$ & toluene $/ \mathrm{Et}_{2} \mathrm{O}$ & 12 & -70 & $92(72)^{f}$ & $94: 6$ \\
\hline
\end{tabular}

${ }^{a}$ Unless indicated otherwise, the optimization reactions (entries 1-17) were performed on 0.1-0.3 mmol scale with 1.5 equiv. of Lewis Acid and 2.5 equiv. of allyl stannane 2. ${ }^{\mathrm{b}}$ Conversion of aldehyde 3 into alcohol 8 and d.r. ratios were determined by ${ }^{1} \mathrm{H}$ NMR. ${ }^{c}$ Complex mixture of products. ${ }^{d}$ The reaction was performed with 3 equiv. of a Lewis acid. ${ }^{\mathrm{e}}$ The use of $\mathrm{Sc}(\mathrm{OTf})_{3}$ pre-dried in vacuum at heating afforded the same d.r. ${ }^{\mathrm{f}}$ The reaction was performed with $11.5 \mathrm{mmol}$ of aldehyde 3 and 1.7 equiv. of 2 in the presence of 1.1 equiv. of the hydrated Sc(OTf $)_{3}$ Isolated yield of anti-8 is given in parentheses.

On the other hand, the presence of a $\beta$-hydroxy-substituted stereocenter in aldehyde 3 ensured an alternative opportunity to carry out the diastereoselective chelation-controlled 1,3 -anti-allylation $[16,17,28-32]$. However, in this case, the ratio of diastereoisomers substantially depends on the choice of protective group as well as Lewis acid [32]. Typically, benzyl or $p$-methoxybenzyl ethers are used [7-13,31,32]. However, these protecting groups were unsuitable according to our planned synthetic route towards (+)-Neopeltolide. Therefore, while keeping the MOM-protection in 3 intact, we began to investigate the effect of various Lewis acids, available at our laboratory (Table 1 ).

First, we tried to carry out the reaction with $\mathrm{TiCl}_{4}$, which is known as an effective catalyst for the chelation-controlled Reetz-Keck-type allylation [28-32]. Unfortunately, a complex mixture of products was formed (Table 1, entry 2). Tin(IV) chloride behaved similarly (entry 3 ), while the less reactive titanium catalysts failed to furnish any products at all (entries 4 and 5). Magnesium bromide as another prominent catalyst [31,32] delivered the desired homoallylic alcohol 8, albeit with moderate diastereoselectivity (entry 6). The ratio of diastereomers was determined by ${ }^{1} \mathrm{H}$ NMR analysis of the crude reaction mixture, by integration of signals at $\delta 2.98(\mathrm{~d}, J=2.9 \mathrm{~Hz})$ and $3.09(\mathrm{~d}, J=2.1 \mathrm{~Hz}) \mathrm{ppm}$, which correspond to hydroxyl protons of anti- and syn-8, respectively. Analogously to $\mathrm{MgBr}_{2}$, zinc and zirconium(IV) chlorides also produced 8 with unsatisfactory diasteroisomeric ratios (entries 7 and 8).

While testing different metal triflates (entries 9-13), we found that allylation of 3 occurred with promising yield and diastereoslectivity in the presence of scandium(III) triflate [72-75]. The reaction mediated by $\mathrm{Sc}(\mathrm{OTf})_{3}$ was especially successful in toluene as solvent (entry 10), while triflates of indium, ytterbium, and hafnium were noticeably less efficient (entries 11-13). During these preliminary tests we also noticed that the stereochemical outcome of the reaction with $\mathrm{Sc}(\mathrm{OTf})_{3}$ and the reactivity of the catalyst were strongly depended on the catalyst batch. While the allylation with an old reagent did not occur at $-70{ }^{\circ} \mathrm{C}$ and required higher temperature $\left(-25^{\circ} \mathrm{C}\right)$, a fresh sample of commercial $\mathrm{Sc}(\mathrm{OTf})_{3}$, as well as the catalyst dried in vacuum at heating, were much more reactive and 
delivered the target alcohol 8 already at $-70{ }^{\circ} \mathrm{C}$ but with noticeably lower $76: 24$ d.r. (entry 10 vs. 14).

We surmised that the difference in reactivity between the batches can be explained by hydration of the old reagent with atmospheric moisture since $\mathrm{Sc}(\mathrm{OTf})_{3}$ is hygroscopic and eventually forms octahydrate upon storage. Indeed, powder X-ray diffraction (PXRD) analysis of the old and new reagent confirmed our hypothesis and showed that the old reagent contained $\mathrm{Sc}(\mathrm{OTf})_{3} \cdot 8 \mathrm{H}_{2} \mathrm{O}$ as the main phase (Figure 1).

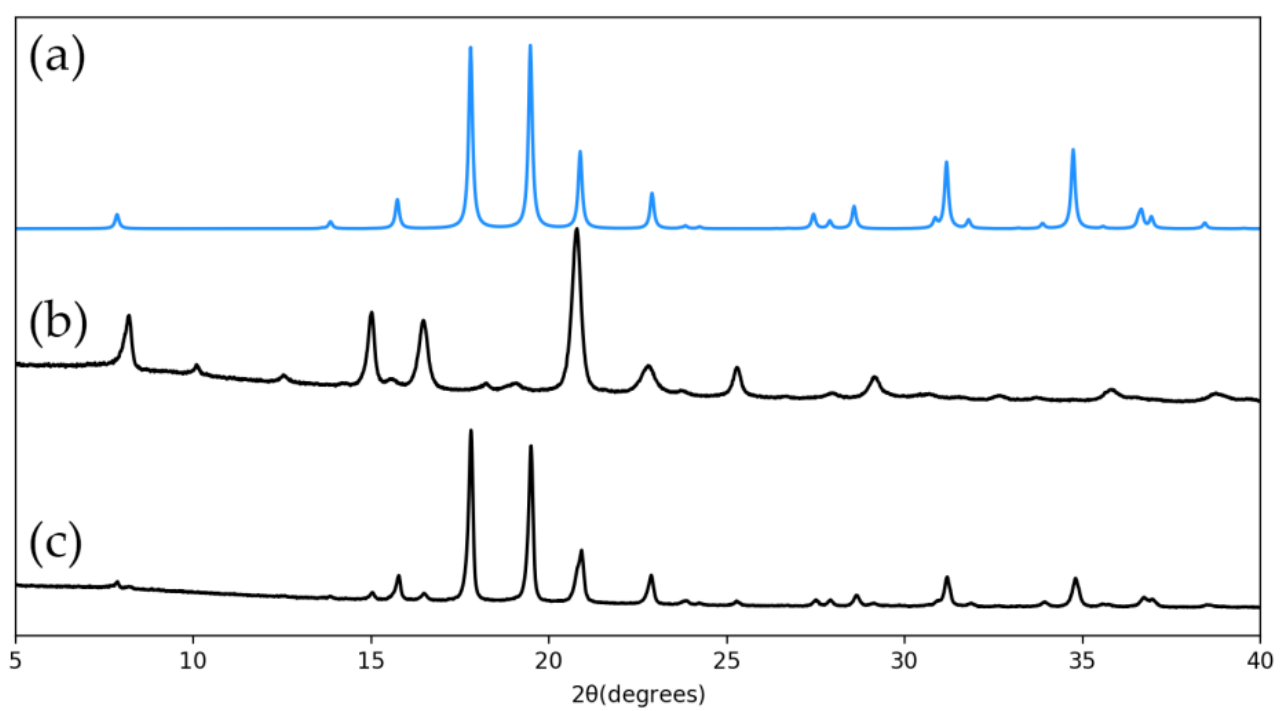

Figure 1. (a) Powder X-ray diffraction (PXRD) patterns calculated for $\mathrm{Sc}(\mathrm{OTf})_{3} \cdot 8 \mathrm{H}_{2} \mathrm{O}$ from the corresponding single-crystal $\mathrm{X}$-ray diffraction data. Crystallographic data are available from the Cambridge Structural Database (CSD 415177). (b) PXRD pattern of commercially available anhydrous $\mathrm{Sc}(\mathrm{OTf})_{3}$. The main phase corresponds to $\mathrm{Sc}(\mathrm{OTf})_{3} \cdot x \mathrm{H}_{2} \mathrm{O}(x<8)$ [76]. Slight hydration occurred since the sample was exposed to atmospheric moisture during the measurement. (c) PXRD patterns of the hydrated reagent, which contains $\mathrm{Sc}(\mathrm{OTf})_{3} \cdot 8 \mathrm{H}_{2} \mathrm{O}$ as the main phase and trace amount of $\mathrm{Sc}(\mathrm{OTf})_{3} \cdot x \mathrm{H}_{2} \mathrm{O}$ phase.

To our delight, controlled addition of water to the anhydrous $\mathrm{Sc}(\mathrm{OTf})_{3}$ allowed to prepare a catalyst with reproducible performance (see the experimental part), similar to those of the old batches (entries 15 and 16). The best outcome and the highest diastereoselectivity was observed when 2 equiv. of water was added. Moreover, we found that addition of diethyl ether as a co-solvent to toluene (ca. 20\% v/v) allows to decrease the reaction temperature to $-70{ }^{\circ} \mathrm{C}$ and therefore further improve the diastereoselectivity (up to 91:9, entry 17). Finally, anti-alcohol 8 was prepared in $72 \%$ isolated yield and with excellent $94: 6$ diastereomeric purity in a preparative reaction run starting from $11.5 \mathrm{mmol}$ of aldehyde 3 (entry 18). It is important to note that at least 1.1 equiv. of hydrated $\mathrm{Sc}(\mathrm{OTf})_{3}$ must be used to attain high yields, probably due to the presence of several oxygen-containing functionalities in $\mathbf{8}$ and formation of a stable chelate complex with scandium.

Our results indicate that controlled hydration of $\mathrm{Sc}(\mathrm{OTf})_{3}$ can be considered as a tool to attenuate the reactivity of $\mathrm{Sc}(\mathrm{OTf})_{3}$ in allylation of carbonyl compounds, and perhaps in other transformations mediated by the same Lewis acid. Scandium(III) triflate has multiple catalytic uses in organic synthesis and can operate even in aqueous media [72-75]. However, the influence of small amounts of water on the catalytic performance of $\mathrm{Sc}(\mathrm{OTf})_{3}$, especially in stereoselective transformations, has been only scarcely reported, to the best of our knowledge [77-79].

The preferred 1,3-anti-selectivity in this transformation can be rationalized in the framework of the Reetz chelate model $[16,17,28-32]$. We assume that the reaction could proceed through the formation of six-membered chelate intermediates I and II (Scheme 4) [9]. 


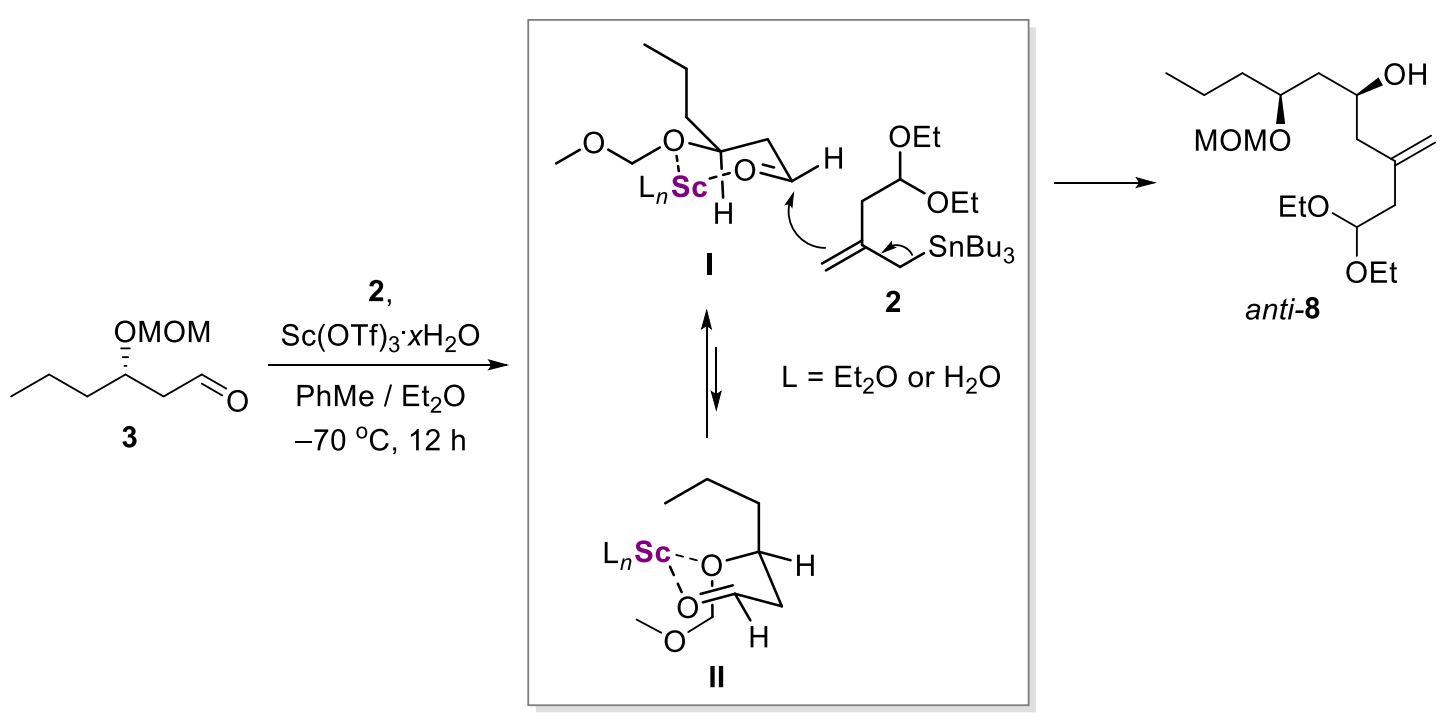

Scheme 4. The proposed stereochemical model explaining the preferred 1,3-anti-selectivity.

Intermediate II is less preferred than I, since $n$-propyl substituent and MOM-protecting group are both occupy axial positions in the former. Moreover, the reaction of I with allylstannane $\mathbf{2}$ leading to anti-alcohol $\mathbf{8}$ should proceed faster since the reagent $\mathbf{2}$ approaches from the least hindered side of the carbonyl group, as shown on Scheme 4. On the contrary, in complex II, both sides of the carbonyl group are sterically shielded with axial $n$-propyl and MOM substituents, which should result in higher activation barrier for the reaction of II with $\mathbf{2}$ in comparison with those of I. Although a mechanistic rationale for the improved d.r. in the case of hydrated catalyst is not fully clear, aqua ligands coordinated to scandium should introduce additional steric hindrances thus further enhancing the difference in reactivity between I and II and shifting the equilibrium towards the less sterically hindered intermediate $\mathbf{I}$.

Having alcohol anti-8 in hand, we confirmed its stereochemical configuration by conversion into the known $C^{7}-C^{16}$ building block of (+)-Neopeltolide (Scheme 5) [55]. Thus, cyclization of $\mathbf{8}$ in the presence of catalytic amount of $p$-toluenesulfonic acid ( $p$ $\mathrm{Ts} \mathrm{OH}$ ) and subsequent mild hydrolysis led to the formation of lactol 9. Oxidation of 9 with pyridinium chlorochromate (PCC) followed by base-catalyzed isomerization of the double bond yielded unsaturated lactone 10. Hydrogenation of $\mathbf{1 0}$ resulted in the formation of saturated lactone $\mathbf{1 1}$ as a single diastereoisomer and in a quantitative yield. Reduction of 11 with $\mathrm{LiAlH}_{4}$ afforded diol 12. To confirm 1,3-anti configuration of the stereocenters, diol 12 was transformed into the corresponding acetonide 13. The values of chemical shifts in ${ }^{13} \mathrm{C}$ NMR spectrum of 13 indicated the 1,3-anti-configuration of hydroxyl groups (Scheme 5), according to a known configuration assignment method [80,81]. The selective TBS-protection of the primary hydroxyl group in compound $\mathbf{1 2}$ and the subsequent methylation of the secondary hydroxyl produced ether 14 in 92\% yield over two steps. Treatment of $\mathbf{1 4}$ with catalytic amount of pyridinium $p$-toluenesulfonate (PPTS) in methanol and subsequent Swern oxidation furnished aldehyde 15 in $92 \%$ yield as a final $C^{7}-C^{16}$ building block of (+)-Neopeltolide. 


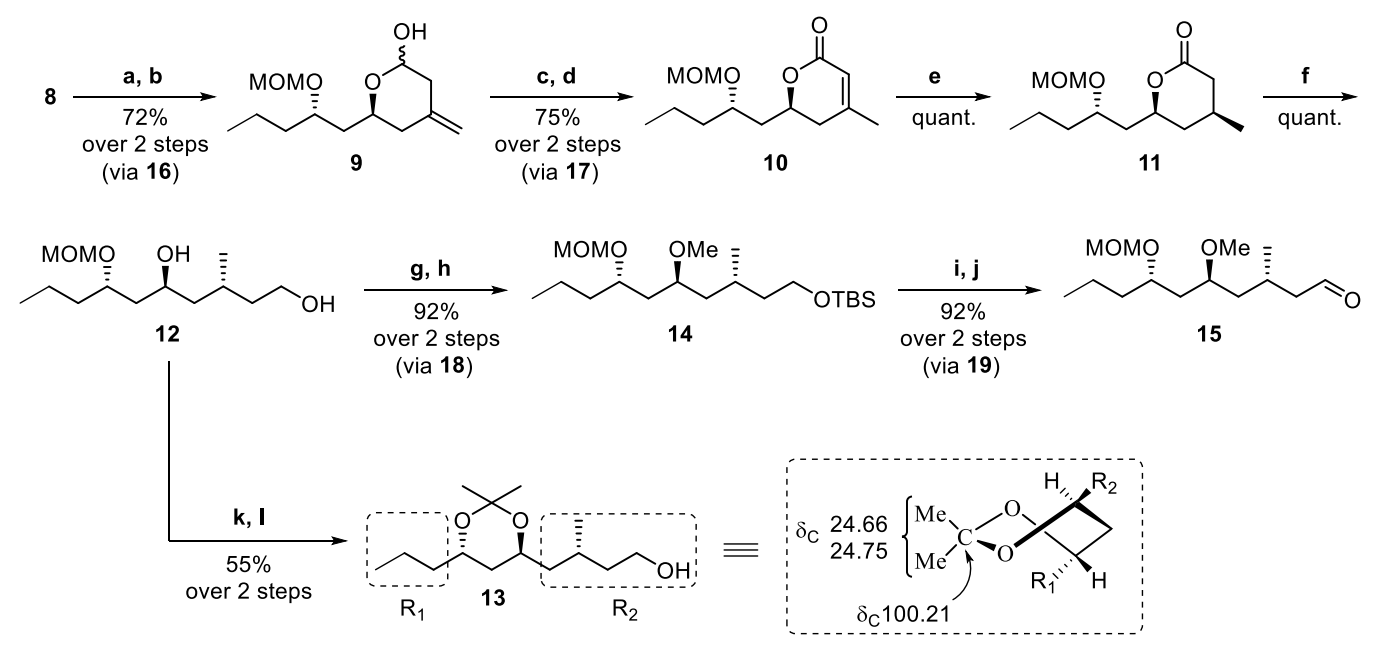

Scheme 5. Assignment of 1,3-anti-configuration for 8 by its chemical conversion into acetonide 13. Preparation of $C^{7}-C^{16}$ building block 15 of (+)-Neopeltolide [55]. Reagents and conditions: (a) $p$ - $\mathrm{TsOH} \cdot \mathrm{H}_{2} \mathrm{O}, \mathrm{CH}_{2} \mathrm{Cl}_{2}, \mathrm{rt}, 40 \mathrm{~min}$ (90\%); (b) PPTS, acetone $/ \mathrm{H}_{2} \mathrm{O}$ (3:1), reflux, $12 \mathrm{~h}(80 \%)$; (c) PCC, $\mathrm{CH}_{2} \mathrm{Cl}_{2}$, r.t., $8 \mathrm{~h}(87 \%)$; (d) $\mathrm{Et}_{3} \mathrm{~N}$, THF, reflux, $5 \mathrm{~h}(86 \%) ;\left(\right.$ e) $10 \% \mathrm{Pd} / \mathrm{C}, \mathrm{H}_{2}$ in i-PrOH, H-Cube $\left(25^{\circ} \mathrm{C}, 5\right.$ bar) $(100 \%)$; (f) $\mathrm{LiAlH}_{4}, \mathrm{Et}_{2} \mathrm{O}$, r.t., $25 \mathrm{~min}(100 \%)$; (g) $\mathrm{TBSCl}$, imidazole, $\mathrm{CH}_{2} \mathrm{Cl}_{2}$, r.t., $1.5 \mathrm{~h}(96 \%)$; (h) $\mathrm{NaH}, \mathrm{MeI}, \mathrm{Bu}_{4} \mathrm{NI}$, THF, r.t., $14 \mathrm{~h}(96 \%)$; (i) PPTS, $\mathrm{MeOH}$, r.t., $15 \mathrm{~h}(98 \%)$; (j) $(\mathrm{COCl})_{2}, \mathrm{DMSO}, \mathrm{CH}_{2} \mathrm{Cl}_{2}, \mathrm{Et}_{3} \mathrm{~N},-78{ }^{\circ} \mathrm{C}$ to $0{ }^{\circ} \mathrm{C}$ (94\%); (k) pTsOH $\cdot \mathrm{H}_{2} \mathrm{O}, \mathrm{MeOH}$, reflux, 2 h; (l) pTsOH$\cdot \mathrm{H}_{2} \mathrm{O}, 2$,2-dimethoxypropane, r.t., $24 \mathrm{~h}$ (55\% for 2 steps). Preparation of intermediate compounds 16-19 (structures not shown here for the reasons of space) is described in the Section 3.

\section{Experimental Section}

\subsection{General Experimental Methods}

Solvents were used as obtained from commercial sources without any further purification or dried if required over $4 \AA$ molecular sieves. Chemicals were purchased from Sigma-Aldrich (St. Louis, MO, USA), Fluorochem (London, UK) and Alfa Aesar (Ward Hill, MA, USA) and used as received unless other indicated. (S)-3-(Methoxymethoxy)hexanal (3) (ee $>99 \%$ ) was prepared as described before [55] (see also the Supplementary Materials). Silica gel $40-100 \mu \mathrm{m}$ was used for column chromatography; silica gel $60 \mathrm{~F}_{254}$ plates were used for TLC. ${ }^{1} \mathrm{H}-\mathrm{NMR}(400 \mathrm{MHz}),{ }^{13} \mathrm{C}-\mathrm{NMR}(100.6 \mathrm{MHz})$ spectra were recorded on Avance III spectrometer (Bruker, Billerica, MA, USA). Chemical shifts are given in $\delta$ value with $\mathrm{CHCl}_{3}(\delta=7.26 \mathrm{ppm})$ and $\mathrm{CDCl}_{3}(\delta=77.0 \mathrm{ppm})$ as internal standards for ${ }^{1} \mathrm{H}-\mathrm{NMR}$ and ${ }^{13} \mathrm{C}-\mathrm{NMR}$ spectra, respectively. FT-IR spectra were recorded on a Bruker Tensor 27 FT spectrometer. Only selected characteristic IR absorption bands are given. Specific rotations were measured by using an Anton Paar MCP 500 polarimeter. HRMS data were obtained on a HPLC/Q-TOF G6540A Mass Spectrometer (Agilent, Santa Clara, CA, USA) using AJS ESI method in positive ion detection modes or a LTQ Orbitrap Discovery spectrometer (Thermo Fisher Scientific, Waltham, MA, USA) using electrospray ionization (ESI). Powder X-ray diffraction (PXRD) patterns for the samples of $\mathrm{Sc}(\mathrm{OTf})_{3}$ were recorded with an EMPYREAN diffractometer (PANalytical, Netherlands) using $\mathrm{Cu}-\mathrm{K} \alpha$ radiation (Ni-filter) at $296 \mathrm{~K}$ with area detector $2 \theta$ range of ca. $0^{\circ}-40^{\circ}$. Samples of $\mathrm{Sc}(\mathrm{OTf})_{3}$ were not protected from atmospheric moisture during the measurements. Crystallographic data for $\mathrm{Sc}(\mathrm{OTf})_{3} \cdot 8 \mathrm{H}_{2} \mathrm{O}$ are available from the Cambridge Structural Database (CSD 415177) [82].

\subsection{Preparation of 4,4-Diethoxy-2-methylenebutyl Bromide (1)}

\subsubsection{1-(2,2-Diethoxyethyl)cyclopropan-1-ol (5)}

A solution of EtMgBr (1.6 M in THF, $200 \mathrm{~mL}, 320 \mathrm{mmol})$ was added dropwise over a period of $7 \mathrm{~h}$ to a solution of ethyl 3,3-diethoxypropionate (4) (20.0 g, $105 \mathrm{mmol})$ and titanium(IV) isopropoxide $(6.0 \mathrm{~mL}, 20 \mathrm{mmol}, 20 \mathrm{~mol} \%)$ in THF $(90 \mathrm{~mL})$ under stirring and external cooling (water bath, $20^{\circ} \mathrm{C}$ ). The reaction mixture was additionally stirred at r.t. for $12 \mathrm{~h}$, at which time the solvent was removed under reduced pressure and the residue was dissolved in $\mathrm{CH}_{2} \mathrm{Cl}_{2}(300 \mathrm{~mL})$. The flask was placed in an ice-water bath and a saturated 
aqueous solution of $\mathrm{NH}_{4} \mathrm{Cl}(38 \mathrm{~mL})$ was added by small portions at vigorous stirring. The mixture was additionally stirred at r.t. for $20 \mathrm{~min}$ and filtered. The precipitate was washed with $\mathrm{CH}_{2} \mathrm{Cl}_{2}(3 \times 150 \mathrm{~mL})$, and the combined organic phases were washed with a saturated aqueous solution of $\mathrm{NaCl}(150 \mathrm{~mL})$ and dried over $\mathrm{Na}_{2} \mathrm{SO}_{4}$. The solvent was removed under reduced pressure to afford cyclopropanol $5(18.3 \mathrm{~g}, 100 \%)$ as a yellowish oil. The obtained compound was used directly in the next step; additional purification was not required. $R_{f}=0.55$ (PE:EtOAc, 4:1). ${ }^{1} \mathrm{H} \mathrm{NMR}\left(400 \mathrm{MHz}, \mathrm{CDCl}_{3}\right): \delta=4.80(\mathrm{t}, J=5.8 \mathrm{~Hz}$, 1H), 3.77-3.68 (m, 2H), 3.59 (br.s, 1H), 3.62-3.51 (m, 2H), 1.89 (d, J = 5.8 Hz, 2H), 1.23 $(\mathrm{t}, J=7.1 \mathrm{~Hz}, 6 \mathrm{H}), 0.78-0.73(\mathrm{~m}, 2 \mathrm{H}), 0.47-0.42(\mathrm{~m}, 2 \mathrm{H}) .{ }^{13} \mathrm{C} \mathrm{NMR}\left(100.6 \mathrm{MHz} \mathrm{CDCl}_{3}\right)$ : $\delta=102.97,61.74(2 \mathrm{C}), 53.13,40.91,15.30$ (2C), 12.40 (2C). Spectral data are in agreement with previously reported [83].

\subsubsection{1-(2,2-Diethoxyethyl)cyclopropyl Methanesulfonate (6)}

A solution of methanesulfonyl chloride $(16.0 \mathrm{~mL}, 205 \mathrm{mmol})$ in anhydrous diethyl ether $(100 \mathrm{~mL})$ was added dropwise over a period of $10 \mathrm{~min}$ to a cooled (ice bath, $0{ }^{\circ} \mathrm{C}$ ) solution of cyclopropanol $5(18.3 \mathrm{~g}, 105 \mathrm{mmol})$ and $N, N$-diisopropylethylamine $(48.0 \mathrm{~mL}$, $275 \mathrm{mmol})$ in anhydrous diethyl ether $(200 \mathrm{~mL})$. The reaction mixture was stirred for $2 \mathrm{~h}$ and during this time gradually warmed to room temperature. A saturated solution of $\mathrm{NaHCO}_{3}$ $(200 \mathrm{~mL})$ was added, and the mixture was stirred for $1 \mathrm{~h}$. The organic layer was separated, the aqueous layer was extracted with diethyl ether $(3 \times 150 \mathrm{~mL})$, and the combined organic extracts were dried over $\mathrm{Na}_{2} \mathrm{SO}_{4}$. The solvent was removed under reduced pressure to afford the crude mesylate $6(26.5 \mathrm{~g}, 100 \%)$ as a pale-orange oil, which was used in the next step without purification. $R_{f}=0.55$ (PE:EtOAc, 4:1). ${ }^{1} \mathrm{H} \mathrm{NMR}\left(400 \mathrm{MHz} \mathrm{CDCl}_{3}\right): \delta=4.80$ $(\mathrm{t}, J=5.4 \mathrm{~Hz}, 1 \mathrm{H}), 3.72-3.62(\mathrm{~m}, 2 \mathrm{H}), 3.59-3.49(\mathrm{~m}, 2 \mathrm{H}), 3.00(\mathrm{~s}, 3 \mathrm{H}), 2.14(\mathrm{~d}, J=5.4 \mathrm{~Hz}$, $2 \mathrm{H}), 1.27-1.22(\mathrm{~m}, 2 \mathrm{H}), 1.20(\mathrm{t}, J=7.1 \mathrm{~Hz}, 6 \mathrm{H}), 0.84-0.78(\mathrm{~m}, 2 \mathrm{H}) .{ }^{13} \mathrm{C} \mathrm{NMR}(100.6 \mathrm{MHz}$, $\left.\mathrm{CDCl}_{3}\right): \delta=100.90,63.79,62.06(2 \mathrm{C}), 40.34,39.84,15.26(2 \mathrm{C}), 11.57(2 \mathrm{C})$. Spectral data are in agreement with previously reported [84].

\subsubsection{4,4-Diethoxy-2-methylenebutyl Bromide (1)}

A solution of 1,2-dibromoethane $(19.0 \mathrm{~mL}, 220 \mathrm{mmol})$ in anhydrous diethyl ether (50 mL) was added slowly in a dropwise manner to magnesium turnings ( $4.8 \mathrm{~g}, 200 \mathrm{mmol})$ in anhydrous diethyl ether $(100 \mathrm{~mL})$. The reaction mixture was additionally stirred until the complete dissolution of magnesium occurred. Then, a solution of the crude mesylate 6 $(26.5 \mathrm{~g}, 105 \mathrm{mmol})$ in anhydrous diethyl ether $(120 \mathrm{~mL})$ was added dropwise over $15 \mathrm{~min}$ at room temperature to the obtained solution of $\mathrm{MgBr}_{2}$ and the resulting mixture was vigorously stirred for $2 \mathrm{~h}$. Afterwards, water $(200 \mathrm{~mL})$ was cautiously added by small portions at external cooling (ice-water bath, $0{ }^{\circ} \mathrm{C}$ ). The organic layer was separated, and the aqueous layer was extracted with diethyl ether $(3 \times 100 \mathrm{~mL})$. The combined organic phases were washed with saturated $\mathrm{NaHCO}_{3}$ solution $(150 \mathrm{~mL})$ and dried over $\mathrm{Na}_{2} \mathrm{SO}_{4}$. The solvent was removed under reduced pressure, and allyl bromide $\mathbf{1}$ was purified by using a short chromatographic column $\left(\mathrm{SiO}_{2}\right.$, eluent PE:EtOAc, 50:1). Yellowish oil (23.4 g, 94\%). $R_{f}=0.63$ (PE:EtOAc, 10:1). ${ }^{1} \mathrm{H} \mathrm{NMR}\left(400 \mathrm{MHz}, \mathrm{CDCl}_{3}\right): \delta=5.25$ (br.s, 1H), 5.06 (br.s, $1 \mathrm{H}), 4.62(\mathrm{t}, J=5.6 \mathrm{~Hz}, 1 \mathrm{H}), 4.04$ (br.s, $2 \mathrm{H}), 3.70-3.61(\mathrm{~m}, 2 \mathrm{H}), 3.55-3.45(\mathrm{~m}, 2 \mathrm{H}), 2.53(\mathrm{~d}$, $J=5.6 \mathrm{~Hz}, 2 \mathrm{H}), 1.19(\mathrm{t}, J=7.1 \mathrm{~Hz}, 6 \mathrm{H}) .{ }^{13} \mathrm{C} \mathrm{NMR}\left(100.6 \mathrm{MHz} \mathrm{CDCl}_{3}\right): \delta=141.38,117.82$, $101.84,61.32(2 \mathrm{C}), 37.50,37.37,15.21(2 \mathrm{C})$. Spectral data are in agreement with previously reported [53].

\subsection{Preparation of Tributyl(4,4-diethoxy-2-methylenebutyl)stannane (2)}

A solution of naphthalene $(0.16 \mathrm{~g}, 1.25 \mathrm{mmol})$ in THF $(2 \mathrm{~mL})$ was added to lithium chipping $(0.60 \mathrm{~g}, 86 \mathrm{mmol})$ in THF $(48 \mathrm{~mL})$ under inert atmosphere (argon). The mixture turned green and was stirred at room temperature for $1 \mathrm{~h}$. Then, tributyltin chloride $(6.50 \mathrm{~mL}, 24.0 \mathrm{mmol})$ was added dropwise, and the mixture was stirred at room temperature for $12 \mathrm{~h}$. The resulting dark-green solution of $\mathrm{Bu}_{3} \mathrm{SnLi}$ was transferred into another reaction vessel and cooled to $-78^{\circ} \mathrm{C}$ (acetone-dry ice bath). A solution of allylbromide $\mathbf{1}$ (4.74 $\mathrm{g}$, 
$20.0 \mathrm{mmol})$ in THF (40 mL) was added dropwise and the resulting reaction mixture was stirred at $-78{ }^{\circ} \mathrm{C}$ for $1 \mathrm{~h}$. The reaction was quenched by addition of saturated aqueous solution of $\mathrm{NH}_{4} \mathrm{Cl}(150 \mathrm{~mL})$ and stirred while warming to room temperature for $1 \mathrm{~h}$. The organic layer was separated, the aqueous layer was extracted with $\mathrm{Et}_{2} \mathrm{O}(3 \times 50 \mathrm{~mL})$, and the combined organic phases were washed with saturated $\mathrm{NaHCO}_{3}$ solution $(50 \mathrm{~mL})$ and dried over $\mathrm{Na}_{2} \mathrm{SO}_{4}$. The solvent was removed under reduced pressure to afford the crude stannane 2 (9.3 g). According to ${ }^{1} \mathrm{H}$ NMR analysis, the crude product contains $7 \mathrm{~g}$ (77 mol.\%, 78\% yield) of 2, contaminated with self-coupling products 7 ( $0.5 \mathrm{~g}, 8 \mathrm{~mol} . \%)$ and $\mathrm{Bu}_{3} \mathrm{SnSnBu}_{3}(1.8 \mathrm{~g}, 15 \mathrm{~mol} \%$ ). However, the crude stannane 2 can be used for the allylation of aldehydes without any further purification.

Tributyl(4,4-diethoxy-2-methylenebutyl)stannane (2): $R_{f}=0.68$ (PE:EtOAc, 20:1). IR (neat): $v=1627,1215,1119,1060 \mathrm{~cm}^{-1} .{ }^{1} \mathrm{H} \mathrm{NMR}\left(400 \mathrm{MHz}, \mathrm{CDCl}_{3}\right): \delta=4.62(\mathrm{t}, J=5.7 \mathrm{~Hz}$, $1 \mathrm{H}), 4.63-4.57(\mathrm{~m}, 1 \mathrm{H}), 4.57-4.51(\mathrm{~m}, 1 \mathrm{H}), 3.70-3.61(\mathrm{~m}, 2 \mathrm{H}), 3.56-3.46(\mathrm{~m}, 2 \mathrm{H}), 2.29-2.23(\mathrm{~m}$, 2H), 1.93-1.75 (m, 2H), 1.56-1.38 (m, 6H), 1.37-1.24 (m, 6H), $1.20(\mathrm{t}, J=7.1 \mathrm{~Hz}, 6 \mathrm{H}), 0.89(\mathrm{t}$, $J=7.3 \mathrm{~Hz}, 6 \mathrm{H}), 0.88(\mathrm{t}, J=7.3 \mathrm{~Hz}, 9 \mathrm{H}) .{ }^{13} \mathrm{C} \mathrm{NMR}\left(100.6 \mathrm{MHz} \mathrm{CDCl}_{3}\right): \delta=145.61,107.34$, $102.31,61.13(2 C), 42.41,29.08(3 C), 27.36(3 C), 19.51,15.30(2 C), 13.68(3 C), 9.44(3 C)$.

1,1,8,8-Tetraethoxy-3,6-dimethyleneoctane (7): $R_{f}=0.5$ (PE:EtOAc, 20:1). ${ }^{1} \mathrm{H} \mathrm{NMR}$ $\left(400 \mathrm{MHz}, \mathrm{CDCl}_{3}\right): \delta=4.83$ (br.s, $\left.4 \mathrm{H}\right), 4.60(\mathrm{t}, \mathrm{J}=5.7 \mathrm{~Hz}, 2 \mathrm{H}), 3.70-3.59(\mathrm{~m}, 4 \mathrm{H}), 3.54-3.43(\mathrm{~m}$, $4 \mathrm{H}), 2.35$ (d, J = 5.7 Hz, 4H), 2.20 (br.s, 4H), 1.19 (t, J = 7.1 Hz, 12H). ${ }^{13} \mathrm{C} \mathrm{NMR}(100.6 \mathrm{MHz}$, $\left.\mathrm{CDCl}_{3}\right): \delta=144.93(2 \mathrm{C}), 111.78(2 \mathrm{C}), 102.09(2 \mathrm{C}), 61.05(4 \mathrm{C}), 40.31(2 \mathrm{C}), 34.66(2 \mathrm{C}), 15.25$ (4C). HRMS (ESI) calcd. for $\mathrm{C}_{18} \mathrm{H}_{34} \mathrm{O}_{4} \mathrm{Na}^{+}[\mathrm{M}+\mathrm{Na}]^{+} 337.2349$, found $m / z$ 337.2347.

\subsection{Preparation of Hydrated Scandium Triflate Catalyst}

Water $(0.76 \mathrm{~mL}, 42 \mathrm{mmol})$ was added to a stirred suspension of anhydrous scandium triflate $(10.3 \mathrm{~g}, 21 \mathrm{mmol})$ in anhydrous diethyl ether $(240 \mathrm{~mL})$. The resulting mixture was stirred until almost complete dissolution of solid occurred. The solvent was removed under reduced pressure. The solid residue was thoroughly grinded with mortar and pestle under air and not protected from atmospheric moisture. The obtained powder was dried on a rotary evaporator at $70^{\circ} \mathrm{C}$ and reduced pressure $(5 \mathrm{~mm} \mathrm{Hg})$ for $3 \mathrm{~h}$.

\section{5. (5S,7S)-1,1-Diethoxy-7-(methoxymethoxy)-3-methylenedecan-5-ol (anti-8)}

A solution of (S)-3-(methoxymethoxy)hexanal (3) $(1.84 \mathrm{~g}, 11.5 \mathrm{mmol})$ in anhydrous toluene $(25 \mathrm{~mL})$, and a solution of tributyl(4,4-diethoxy-2-methylenebutyl)stannane (2) $(9.20 \mathrm{~g}, 20.6 \mathrm{mmol})$ in anhydrous toluene $(30 \mathrm{~mL})$ were sequentially added to a turbid solution of freshly prepared hydrated scandium triflate catalyst $(8.04 \mathrm{~g}, 12.6 \mathrm{mmol})$ in a mixture of anhydrous toluene $(55 \mathrm{~mL})$ and diethyl ether $(27 \mathrm{~mL})$ at $-70{ }^{\circ} \mathrm{C}$ under inert atmosphere (argon). The reaction mixture was stirred at $-70{ }^{\circ} \mathrm{C}$ for $12 \mathrm{~h}$. (TLC monitoring clearly revealed the product only after aqueous work up of the samples taken). The reaction mixture was quenched with saturated aqueous solution of $\mathrm{NaHCO}_{3}(150 \mathrm{~mL})$ and vigorously stirred until it warmed to room temperature (ca. $1 \mathrm{~h})$. The organic layer was separated, and the aqueous layer was extracted with diethyl ether $(3 \times 100 \mathrm{~mL})$. The combined organic extracts were dried over $\mathrm{Na}_{2} \mathrm{SO}_{4}$. The solvent was removed under reduced pressure, and the title compound was isolated by column chromatography $\left(\mathrm{SiO}_{2}\right.$, eluent PE:EtOAc, gradient 10:1 to 4:1). Colorless oil (2.63 g, 72\%). $R_{f}=0.36$ (PE:EtOAc, 4:1). $[\alpha]_{\mathrm{D}}{ }^{20}=+24.7\left(c 0.69, \mathrm{CH}_{2} \mathrm{Cl}_{2}\right)$. IR (neat): $v=3474,1644,1444,1374,1130,1042,916 \mathrm{~cm}^{-1}$. ${ }^{1} \mathrm{H} \mathrm{NMR}\left(400 \mathrm{MHz} \mathrm{CDCl}_{3}\right): \delta=4.95(\mathrm{~s}, 1 \mathrm{H}), 4.94(\mathrm{~s}, 1 \mathrm{H}), 4.67(\mathrm{~s}, 2 \mathrm{H}), 4.63(\mathrm{t}, J=5.8 \mathrm{~Hz}$, $1 \mathrm{H}), 4.06-3.95(\mathrm{~m}, 1 \mathrm{H}), 3.86-3.77(\mathrm{~m}, 1 \mathrm{H}), 3.70-3.59(\mathrm{~m}, 2 \mathrm{H}), 3.54-3.44(\mathrm{~m}, 2 \mathrm{H}), 3.39(\mathrm{~s}, 3 \mathrm{H})$, $2.98(\mathrm{~d}, J=2.9 \mathrm{~Hz}, 1 \mathrm{H}), 2.47-2.32(\mathrm{~m}, 2 \mathrm{H}), 2.27-2.14(\mathrm{~m}, 2 \mathrm{H}), 1.64-1.26(\mathrm{~m}, 6 \mathrm{H}), 1.18(\mathrm{t}$, $J=7.0 \mathrm{~Hz}, 6 \mathrm{H}), 0.91(\mathrm{t}, J=7.3 \mathrm{~Hz}, 3 \mathrm{H}) .{ }^{13} \mathrm{C} \mathrm{NMR}\left(100.6 \mathrm{MHz} \mathrm{CDCl}_{3}\right): \delta=142.33,115.07$, $102.28,96.25,75.53,65.66,61.30,61.14,55.69,45.35,41.55,39.82,37.26,18.51,15.21,15.18$, 14.19. HRMS (ESI) calcd. for $\mathrm{C}_{17} \mathrm{H}_{34} \mathrm{O}_{5} \mathrm{Na}^{+}[\mathrm{M}+\mathrm{Na}]^{+} 341.2298$, found $m / z$ 341.2296. 
3.6. Preparation of $C^{7}-C^{16}$ Building Block 15 for the Synthesis of (+)-Neopeltolide

3.6.1. (6S)-2-Ethoxy-6-((S)-2-(methoxymethoxy)pentyl)-4-methylenetetrahydro-2H-pyran (16)

$p$-Toluenesulfonic acid monohydrate $\left(p-\mathrm{TsOH} \cdot \mathrm{H}_{2} \mathrm{O}, 0.06 \mathrm{~g}, 0.32 \mathrm{mmol}\right)$ was added to a solution of alcohol $8(5.20 \mathrm{~g}, 16.4 \mathrm{mmol})$ in $\mathrm{CH}_{2} \mathrm{Cl}_{2}(125 \mathrm{~mL})$ and the reaction mixture was stirred at room temperature for $30 \mathrm{~min}$, at which time $\mathrm{Et}_{3} \mathrm{~N}(0.20 \mathrm{~mL}, 1.45 \mathrm{mmol})$ was added. The solvent was removed under reduced pressure and acetal 18 (mixture of epimers 50:50 according to $\left.{ }^{1} \mathrm{H} \mathrm{NMR}\right)$ was isolated by column chromatography $\left(\mathrm{SiO}_{2}\right.$, eluent PE:EtOAc, 20:1). Colorless oil ( $4.01 \mathrm{~g}, 90 \%) . R_{f}=0.60$ (PE:EtOAc, 4:1). IR (neat): $v=1655,1443,1374$, $1350,1215,1145,1042,918,890 \mathrm{~cm}^{-1} .{ }^{1} \mathrm{H}$ NMR $\left(400 \mathrm{MHz}, \mathrm{CDCl}_{3}\right): \delta=4.90(\mathrm{~d}, J=3.4 \mathrm{~Hz}$, $1 \mathrm{H}), 4.80-4.74(\mathrm{~m}, 4 \mathrm{H}), 4.68(\mathrm{~d}, J=6.8 \mathrm{~Hz}, 1 \mathrm{H}), 4.65(\mathrm{~s}, 2 \mathrm{H}), 4.61(\mathrm{~d}, J=6.8 \mathrm{~Hz}, 1 \mathrm{H}), 4.32(\mathrm{dd}$, $J=9.6,2.4 \mathrm{~Hz}, 1 \mathrm{H}), 4.02-3.93(\mathrm{~m}, 1 \mathrm{H}), 3.93-3.81(\mathrm{~m}, 2 \mathrm{H}), 3.76-3.64(\mathrm{~m}, 2 \mathrm{H}), 3.57-3.41(\mathrm{~m}$, $3 \mathrm{H}), 3.36(\mathrm{~s}, 6 \mathrm{H}), 2.45-2.08(\mathrm{~m}, 6 \mathrm{H}), 2.05-1.89(\mathrm{~m}, 2 \mathrm{H}), 1.77-1.30(\mathrm{~m}, 12 \mathrm{H}), 1.24(\mathrm{t}, J=7.1 \mathrm{~Hz}$, $3 \mathrm{H}), 1.18(\mathrm{t}, J=7.1 \mathrm{~Hz}, 3 \mathrm{H}), 0.91(\mathrm{t}, J=7.2 \mathrm{~Hz}, 3 \mathrm{H}), 0.91(\mathrm{t}, J=7.2 \mathrm{~Hz}, 3 \mathrm{H}) .{ }^{13} \mathrm{C}$ NMR $\left(100.6 \mathrm{MHz}, \mathrm{CDCl}_{3}\right): \delta=142.61,140.67,110.52,110.39,101.70,97.07,96.12,96.00,75.27$, 74.20, 71.64, 66.63, 64.34, 62.46, 55.62, 55.56, 41.53, 41.30, 40.97, 40.64, 40.51, 39.04, 37.61, $37.47,18.12,18.11,15.20,14.89,14.26,14.24$. HRMS (ESI) calcd. for $\mathrm{C}_{15} \mathrm{H}_{28} \mathrm{O}_{4} \mathrm{Na}^{+}[\mathrm{M}+\mathrm{Na}]^{+}$ 295.1880, found $m / z 295.1879$.

\subsection{2. (6S)-6-((S)-2-(Methoxymethoxy)pentyl)-4-methylenetetrahydro-2H-pyran-2-ol (9)}

Pyridinium $p$-toluenesulfonate (PPTS, $4.56 \mathrm{~g}, 18.2 \mathrm{mmol}$ ) was added to a solution of cyclic acetal 16 ( $3.80 \mathrm{~g}, 14.0 \mathrm{mmol})$ in a mixture of acetone $(600 \mathrm{~mL})$ and $\mathrm{H}_{2} \mathrm{O}(200 \mathrm{~mL})$ and the reaction mixture was stirred under gentle reflux for $12 \mathrm{~h}$. After cooling to room temperature acetone was evaporated under reduced pressure and the reaction product was extracted from the water phase with $\mathrm{CH}_{2} \mathrm{Cl}_{2}(3 \times 150 \mathrm{~mL})$. The combined organic extracts were washed with saturated aqueous $\mathrm{NaHCO}_{3}$ solution $(100 \mathrm{~mL})$ and dried over $\mathrm{Na}_{2} \mathrm{SO}_{4}$. The solvent was removed under reduced pressure and the title compound was isolated by column chromatography $\left(\mathrm{SiO}_{2}\right.$, eluent PE:EtOAc, 10:1). Obtained as $~ 50: 50$ mixture of epimers according to ${ }^{1} \mathrm{H}$ NMR. Colorless oil $(2.73 \mathrm{~g}, 80 \%) . R_{f}=0.45$ (PE:EtOAc, 2:1). IR (neat): $v=3417,1655,1441,1378,1334,1214,1140,1101,1039,895 \mathrm{~cm}^{-1} .{ }^{1} \mathrm{H}$ NMR $\left(400 \mathrm{MHz}, \mathrm{CDCl}_{3}\right): \delta=5.38-5.33(\mathrm{~m}, 1 \mathrm{H}), 4.86-4.83(\mathrm{~m}, 1 \mathrm{H}), 4.83-4.80(\mathrm{~m}, 1 \mathrm{H}), 4.79-4.76$ $(\mathrm{m}, 2 \mathrm{H}), 4.67-4.58(\mathrm{~m}, 5 \mathrm{H}), 4.23(\mathrm{~d}, J=5.3 \mathrm{~Hz}, 1 \mathrm{H}), 4.14-4.05(\mathrm{~m}, 1 \mathrm{H}), 3.87-3.78(\mathrm{~m}, 1 \mathrm{H})$, $3.78-3.69(\mathrm{~m}, 1 \mathrm{H}), 3.55(\mathrm{dd}, J=3.9,1.4 \mathrm{~Hz}, 1 \mathrm{H}), 3.51(\mathrm{ddt}, J=11.9,9.6,2.7 \mathrm{~Hz}, 1 \mathrm{H}), 3.37(\mathrm{~s}$, $3 \mathrm{H}), 3.36(\mathrm{~s}, 3 \mathrm{H}), 2.53-1.87(\mathrm{~m}, 8 \mathrm{H}), 1.75-1.28(\mathrm{~m}, 12 \mathrm{H}), 0.90(\mathrm{t}, J=7.2 \mathrm{~Hz}, 6 \mathrm{H}) .{ }^{13} \mathrm{C} \mathrm{NMR}$ $\left(100.6 \mathrm{MHz}, \mathrm{CDCl}_{3}\right): \delta=142.36,140.39,111.35,110.61,96.70,96.05,95.75,92.04,75.26,74.03$, $71.84,66.19,55.65,55.58,42.07,41.39,41.26,40.67,40.22,39.62,37.90,37.47,18.38,18.17$, 14.22, 14.18. HRMS (ESI) calcd. for $\mathrm{C}_{13} \mathrm{H}_{24} \mathrm{O}_{4} \mathrm{Na}^{+}[\mathrm{M}+\mathrm{Na}]^{+} 267.1567$, found $m / z 267.1567$.

3.6.3. ((S)-6-((S)-2-(Methoxymethoxy)pentyl)-4-methylenetetrahydro-2H-pyran-2-one (17)

Pyridinium chlorochromate (PCC, $15.9 \mathrm{~g}, 73.8 \mathrm{mmol}$ ) was added to a solution of lactole $9(3.60 \mathrm{~g}, 14.8 \mathrm{mmol})$ in anhydrous $\mathrm{CH}_{2} \mathrm{Cl}_{2}(170 \mathrm{~mL})$ and the reaction mixture was vigorously stirred at room temperature for $8 \mathrm{~h}$. Diethyl ether $(200 \mathrm{~mL})$ was added, and the mixture was filtrated through a layer of silica gel. Precipitate of chromium salts was washed with diethyl ether $(2 \times 100 \mathrm{~mL})$ and the collected ether solution was filtrated through a layer of silica gel again. The organic extracts were combined; the solvent was removed under reduced pressure. Chromatography purification $\left(\mathrm{SiO}_{2}\right.$, eluent PE:EtOAc, 10:1) afforded lactone 17 as colorless oil (3.10 g, 87\% yield). $R_{f}=0.45$ (PE:EtOAc, 2:1). $[\alpha]_{\mathrm{D}}{ }^{20}$ $=+44.1$ (c 1.30, $\mathrm{CH}_{2} \mathrm{Cl}_{2}$ ). IR (neat): $v=1750,1655,1376,1290,1237,1151,1096,1041 \mathrm{~cm}^{-1}$. ${ }^{1} \mathrm{H}$ NMR $\left(400 \mathrm{MHz}, \mathrm{CDCl}_{3}\right): \delta=4.94$ (br.s, $\left.2 \mathrm{H}\right), 4.67(\mathrm{~d}, J=6.7 \mathrm{~Hz}, 1 \mathrm{H}), 4.64(\mathrm{~d}, J=6.7 \mathrm{~Hz}$, $1 \mathrm{H}), 4.61-4.51(\mathrm{~m}, 1 \mathrm{H}), 3.91-3.78(\mathrm{~m}, 1 \mathrm{H}), 3.35(\mathrm{~s}, 3 \mathrm{H}), 3.37-3.19(\mathrm{~m}, 2 \mathrm{H}), 2.75-2.55(\mathrm{~m}$, $1 \mathrm{H}), 2.33(\mathrm{ddd}, J=15.7,10.8,1.6 \mathrm{~Hz}, 1 \mathrm{H}), 1.84-1.62(\mathrm{~m}, 2 \mathrm{H}), 1.62-1.28(\mathrm{~m}, 4 \mathrm{H}), 0.91(\mathrm{t}$, $J=7.3 \mathrm{~Hz}, 3 \mathrm{H}) .{ }^{13} \mathrm{C}$ NMR $\left(100.6 \mathrm{MHz}, \mathrm{CDCl}_{3}\right): \delta=170.36,135.81,112.17,96.18,75.45,74.02$, $55.60,40.71,38.32,37.21,36.65,18.01,14.18$. HRMS (ESI) calcd. for $\mathrm{C}_{13} \mathrm{H}_{22} \mathrm{O}_{4} \mathrm{Na}^{+}[\mathrm{M}+\mathrm{Na}]^{+}$ 265.1410 , found $m / z 265.1410$. 
3.6.4. (S)-6-((S)-2-(Methoxymethoxy)pentyl)-4-methyl-5,6-dihydro-2H-pyran-2-one (10)

Triethylamine $(1.86 \mathrm{~mL}, 1.36 \mathrm{~g}, 13.5 \mathrm{mmol})$ was added to a solution of lactone $\mathbf{1 7}$ $(2.90 \mathrm{~g}, 12.0 \mathrm{mmol})$ in THF $(50 \mathrm{~mL})$ and the reaction mixture was stirred under gentle reflux for $5 \mathrm{~h}$. After cooling to room temperature, the solvent was removed under reduced pressure and the residue was purified by column chromatography $\left(\mathrm{SiO}_{2}\right.$, eluent PE:EtOAc, 5:1). Colorless oil (2.50 g, 86\%). $R_{f}=0.41$ (PE:EtOAc, 2:1). $[\alpha]_{\mathrm{D}}{ }^{20}=-20.6\left(c 0.75, \mathrm{CH}_{2} \mathrm{Cl}_{2}\right)$. IR (neat): $v=1722,1437,1386,1247,1149,1096,1038 \mathrm{~cm}^{-1} .{ }^{1} \mathrm{H}$ NMR $\left(400 \mathrm{MHz}, \mathrm{CDCl}_{3}\right)$ : $\delta=5.79$ (br.s, $1 \mathrm{H}), 4.67(\mathrm{~d}, J=6.7 \mathrm{~Hz}, 1 \mathrm{H}), 4.65(\mathrm{~d}, J=6.7 \mathrm{~Hz}, 1 \mathrm{H}), 4.66-4.55(\mathrm{~m}, 1 \mathrm{H})$, 3.94-3.82 (m, 1H), $3.35(\mathrm{~s}, 3 \mathrm{H}), 2.38-2.24(\mathrm{~m}, 1 \mathrm{H}), 2.18(\mathrm{dd}, J=17.8,4.0 \mathrm{~Hz}, 1 \mathrm{H}), 1.96$ (br.s, $3 \mathrm{H}), 1.90(\mathrm{ddd}, J=14.5,9.6,2.8 \mathrm{~Hz}, 1 \mathrm{H}), 1.68(\mathrm{ddd}, J=14.5,9.8,2.9 \mathrm{~Hz}, 1 \mathrm{H}), 1.63-1.27$ $(\mathrm{m}, 4 \mathrm{H}), 0.91(\mathrm{t}, J=7.3 \mathrm{~Hz}, 3 \mathrm{H}) .{ }^{13} \mathrm{C}$ NMR $\left(100.6 \mathrm{MHz}, \mathrm{CDCl}_{3}\right): \delta=165.07,157.16,116.48$, 96.16, 74.05, 73.75, 55.64, 40.43, 37.22, 35.25, 22.92, 18.01, 14.21. HRMS (ESI) calcd. for $\mathrm{C}_{13} \mathrm{H}_{22} \mathrm{O}_{4} \mathrm{Na}^{+}[\mathrm{M}+\mathrm{Na}]^{+}$265.1410, found $m / z$ 265.1405.

3.6.5. (4S,6S)-6-((S)-2-(Methoxymethoxy)pentyl)-4-methyltetrahydro-2H-pyran-2-one (11)

A solution of lactone $10(2.4 \mathrm{~g}, 10 \mathrm{mmol})$ in 2-propanol $(0.05 \mathrm{M}, 200 \mathrm{~mL})$ was subjected to flow hydrogenation with the aid of Thales Nano H-Cube ${ }^{\mathrm{TM}}$ flow reactor. The solution of starting material was passed through an $\mathrm{H}$-Cube reactor with a flow rate of $1 \mathrm{~mL} / \mathrm{min}$ at $25^{\circ} \mathrm{C}$ and at 5 bar hydrogen pressure, using a $10 \% \mathrm{Pd} / \mathrm{C} 30 \mathrm{~mm}$-length cartridge. The solvent was evaporated, yielding compound 11 as colorless oil (2.42 $\mathrm{g}$, quantitative yield). $R_{f}=0.53$ (PE:EtOAc, 2:1). $[\alpha]_{\mathrm{D}}{ }^{20}=+70.0\left(c 0.78, \mathrm{CH}_{2} \mathrm{Cl}_{2}\right)$. IR (neat): $v=1737,1458,1379$, 1236, 1153, 1097, $1041 \mathrm{~cm}^{-1}$. ${ }^{1} \mathrm{H}$ NMR $\left(400 \mathrm{MHz}, \mathrm{CDCl}_{3}\right): \delta=4.65(\mathrm{~s}, 2 \mathrm{H}), 4.47(\mathrm{ddt}$, $J=12.1,9.3,3.0 \mathrm{~Hz}, 1 \mathrm{H}), 3.90-3.81(\mathrm{~m}, 1 \mathrm{H}), 3.34(\mathrm{~s}, 3 \mathrm{H}), 2.71-2.59(\mathrm{~m}, 1 \mathrm{H}), 2.12-1.96(\mathrm{~m}$, $2 \mathrm{H}), 1.92-1.82(\mathrm{~m}, 1 \mathrm{H}), 1.74(\mathrm{ddd}, J=14.6,9.3,3.2 \mathrm{~Hz}, 1 \mathrm{H}), 1.65(\mathrm{ddd}, J=14.6,9.5,3.1 \mathrm{~Hz}$, $1 \mathrm{H}), 1.60-1.26(\mathrm{~m}, 4 \mathrm{H}), 1.25-1.13(\mathrm{~m}, 1 \mathrm{H}), 1.01(\mathrm{~d}, J=6.3 \mathrm{~Hz}, 3 \mathrm{H}), 0.90(\mathrm{t}, J=7.3 \mathrm{~Hz}, 3 \mathrm{H}) .{ }^{13} \mathrm{C}$ NMR $\left(100.6 \mathrm{MHz}, \mathrm{CDCl}_{3}\right): \delta=171.27,96.22,77.13,73.96,55.58,41.70,37.95,37.59,37.27$, $26.68,21.65,17.98,14.19$. HRMS (ESI) calcd. for $\mathrm{C}_{13} \mathrm{H}_{24} \mathrm{O}_{4} \mathrm{Na}^{+}[\mathrm{M}+\mathrm{Na}]^{+} 267.1567$, found $m / z 267.1568$.

3.6.6. (3R,5S,7S)-7-(Methoxymethoxy)-3-methyldecane-1,5-diol (12)

A solution of lactone $11(1.42 \mathrm{~g}, 5.8 \mathrm{mmol})$ in anhydrous diethyl ether $(12 \mathrm{~mL})$ was added dropwise to a suspension of $\mathrm{LiAlH}_{4}(0.22 \mathrm{~g}, 5.8 \mathrm{mmol})$ in anhydrous diethyl ether $(12 \mathrm{~mL})$ and the reaction mixture was stirred at room temperature under inert atmosphere (argon) for $25 \mathrm{~min}$. The reaction mixture was diluted with diethyl ether $(50 \mathrm{~mL})$ followed by slow dropwise addition of water (ca. $2 \mathrm{~mL}$ ) upon external cooling with an ice-bath. White precipitate was filtered off, washed with diethyl ether $(3 \times 20 \mathrm{~mL})$, and combined organic phases were dried over $\mathrm{Na}_{2} \mathrm{SO}_{4}$. The solvent was evaporated under reduced pressure, yielding compound 12 as colorless oil (1.44 g, quantitative yield), which was used in the next step without further purification. $R_{f}=0.34$ (EtOAc). $[\alpha]_{\mathrm{D}}{ }^{20}=+40.2\left(c 0.90, \mathrm{CH}_{2} \mathrm{Cl}_{2}\right)$. IR (neat): $v=3385,1463,1378,1147,1098,1041 \mathrm{~cm}^{-1} .{ }^{1} \mathrm{H} \mathrm{NMR}\left(400 \mathrm{MHz}, \mathrm{CDCl}_{3}\right): \delta=4.67(\mathrm{~d}$, $J=6.7 \mathrm{~Hz}, 1 \mathrm{H}), 4.64(\mathrm{~d}, J=6.7 \mathrm{~Hz}, 1 \mathrm{H}), 4.00-3.91(\mathrm{~m}, 1 \mathrm{H}), 3.82-3.75(\mathrm{~m}, 1 \mathrm{H}), 3.74-3.59(\mathrm{~m}$, $2 \mathrm{H}), 3.40(\mathrm{~s}, 3 \mathrm{H}), 3.35(\mathrm{~d}, J=3.0 \mathrm{~Hz}, 1 \mathrm{H}), 2.43(\mathrm{t}, J=5.6 \mathrm{~Hz}, 1 \mathrm{H}), 1.93-1.81(\mathrm{~m}, 1 \mathrm{H}), 1.62-1.41$ $(\mathrm{m}, 7 \mathrm{H}), 1.40-1.27(\mathrm{~m}, 2 \mathrm{H}), 1.14-1.05(\mathrm{~m}, 1 \mathrm{H}), 0.93(\mathrm{~d}, J=6.7 \mathrm{~Hz}, 3 \mathrm{H}), 0.91(\mathrm{t}, J=7.2 \mathrm{~Hz}, 3 \mathrm{H})$ ${ }^{13} \mathrm{C}$ NMR $\left(100.6 \mathrm{MHz}, \mathrm{CDCl}_{3}\right): \delta=96.42,76.04,65.73,60.45,55.83,44.15,42.28,40.37,37.21$, $26.06,20.05,18.65,14.16$. HRMS (ESI) calcd. for $\mathrm{C}_{13} \mathrm{H}_{28} \mathrm{O}_{4} \mathrm{Na}^{+}[\mathrm{M}+\mathrm{Na}]^{+} 271.1880$, found $m / z 271.1877$.

\subsection{7. (R)-4-((4S,6S)-2,2-Dimethyl-6-propyl-1,3-dioxan-4-yl)-3-methylbutan-1-ol (13)}

Two small crystals of $p-\mathrm{TsOH} \cdot \mathrm{H}_{2} \mathrm{O}$ were added to a solution of diol $\mathbf{1 2}(15 \mathrm{mg}$, $0.06 \mathrm{mmol})$ in methanol $(1 \mathrm{~mL})$ and the reaction mixture was stirred under gentle reflux for $2 \mathrm{~h}$. After cooling to room temperature, the solvent was evaporated under reduced pressure, the residue was dissolved in 2,2-dimethoxypropane $(1 \mathrm{~mL})$ and two small crystals of pTsOH$\cdot \mathrm{H}_{2} \mathrm{O}$ were added again. The reaction mixture was stirred at room temperature for $24 \mathrm{~h}$. One drop of triethylamine was added, the solvent was evaporated under reduced 
pressure, and the title compound was isolated by column chromatography $\left(\mathrm{SiO}_{2}\right.$, eluent PE:EtOAc, 7:1). Colorless oil (8 mg, 55\%). $R_{f}=0.45$ (PE:EtOAc, 2:1). $[\alpha]_{\mathrm{D}}{ }^{20}=+27.3(c 0.17$, $\left.\mathrm{CH}_{2} \mathrm{Cl}_{2}\right)$. IR (neat): $v=3406,1460,1379,1225,1172,1134,1053 \mathrm{~cm}^{-1} .{ }^{1} \mathrm{H}$ NMR $(400 \mathrm{MHz}$, $\left.\mathrm{CDCl}_{3}\right): \delta=3.87(\mathrm{dtd}, J=11.2,7.8,3.4 \mathrm{~Hz}, 1 \mathrm{H}), 3.81-3.59(\mathrm{~m}, 3 \mathrm{H}), 1.85-1.62(\mathrm{~m}, 2 \mathrm{H})$, $1.62-1.23(\mathrm{~m}, 8 \mathrm{H}), 1.34(\mathrm{~s}, 3 \mathrm{H}), 1.33(\mathrm{~s}, 3 \mathrm{H}), 1.19(\mathrm{ddd}, J=14.0,8.6,3.4 \mathrm{~Hz}, 1 \mathrm{H}), 0.92(\mathrm{~d}$, $J=6.7 \mathrm{~Hz}, 3 \mathrm{H}), 0.91(\mathrm{t}, J=7.1 \mathrm{~Hz}, 3 \mathrm{H}) .{ }^{13} \mathrm{C} \mathrm{NMR}\left(100.6 \mathrm{MHz} \mathrm{CDCl}_{3}\right): \delta=100.21,66.41$, $64.83,60.76,42.89,40.13,39.44,38.03,26.18,24.75,24.66,19.83,18.58,13.94$. HRMS (ESI) calcd. for $\mathrm{C}_{14} \mathrm{H}_{28} \mathrm{O}_{3} \mathrm{Na}^{+}[\mathrm{M}+\mathrm{Na}]^{+} 267.1931$, found $m / z 267.1929$.

3.6.8. (5S,7S,9R)-9,13,13,14,14-Pentamethyl-5-propyl-2,4,12-trioxa-13-silapentadecan-7-ol (18)

tert-Butyldimethylsilyl chloride $(1.51 \mathrm{~g}, 10.0 \mathrm{mmol})$ was added to a solution of diol 12 (2.34 g, $9.4 \mathrm{mmol})$ and imidazole $(0.90 \mathrm{~g}, 13.2 \mathrm{mmol})$ in anhydrous $\mathrm{CH}_{2} \mathrm{Cl}_{2}(30 \mathrm{~mL})$ at $0{ }^{\circ} \mathrm{C}$ and the reaction mixture was stirred for $1.5 \mathrm{~h}$ while gradually warming to room temperature. Then water $(30 \mathrm{~mL})$ was added, the organic layer was separated, and the aqueous layer was extracted with $\mathrm{CH}_{2} \mathrm{Cl}_{2}(3 \times 30 \mathrm{~mL})$. The combined organic extracts were washed with saturated aqueous $\mathrm{NaHCO}_{3}$ solution $(20 \mathrm{~mL})$ and dried over $\mathrm{Na}_{2} \mathrm{SO}_{4}$. Solvent was removed under reduced pressure, and the reaction product was isolated by column chromatography $\left(\mathrm{SiO}_{2}\right.$, eluent PE:EtOAc, 15:1). Colorless oil $(3.25 \mathrm{~g}, 96 \%) . R_{f}=0.43$ (PE:EtOAc, 4:1). $[\alpha]_{\mathrm{D}}{ }^{20}=+30.5$ (c 1.18, $\mathrm{CH}_{2} \mathrm{Cl}_{2}$ ). IR (neat): $v=3474,1464,1380,1255,1147$, 1096, 1040, 837, $776 \mathrm{~cm}^{-1}$. ${ }^{1} \mathrm{H}$ NMR $\left(400 \mathrm{MHz}, \mathrm{CDCl}_{3}\right): \delta=4.68(\mathrm{~d}, J=6.7 \mathrm{~Hz}, 1 \mathrm{H}), 4.65$ $(\mathrm{d}, J=6.7 \mathrm{~Hz}, 1 \mathrm{H}), 4.02-3.92(\mathrm{~m}, 1 \mathrm{H}), 3.85-3.76(\mathrm{~m}, 1 \mathrm{H}), 3.72-3.59(\mathrm{~m}, 2 \mathrm{H}), 3.41(\mathrm{~s}, 3 \mathrm{H})$, $2.93(\mathrm{~d}, J=3.6 \mathrm{~Hz}, 1 \mathrm{H}), 1.88-1.75(\mathrm{~m}, 1 \mathrm{H}), 1.64-1.27(\mathrm{~m}, 9 \mathrm{H}), 1.19-1.09(\mathrm{~m}, 1 \mathrm{H}), 0.92(\mathrm{~d}$, $J=6.6 \mathrm{~Hz}, 3 \mathrm{H}), 0.92(\mathrm{t}, J=7.3 \mathrm{~Hz}, 3 \mathrm{H}), 0.88(\mathrm{~s}, 9 \mathrm{H}), 0.04(\mathrm{~s}, 6 \mathrm{H}) .{ }^{13} \mathrm{C} \mathrm{NMR}(100.6 \mathrm{MHz}$, $\left.\mathrm{CDCl}_{3}\right): \delta=96.40,76.01,65.45,61.45,55.85,44.99,42.13,40.54,37.22,26.32,25.96(3 \mathrm{C}), 19.58$, $18.68,18.31,14.20,-5.28$ (2C). HRMS (ESI) calcd. for $\mathrm{C}_{19} \mathrm{H}_{42} \mathrm{O}_{4} \mathrm{SiNa}^{+}[\mathrm{M}+\mathrm{Na}]^{+} 385.2745$, found $m / z 385.2744$.

3.6.9. (5S,7S,9R)-7-Methoxy-9,13,13,14,14-pentamethyl-5-propyl-2,4,12-trioxa-13silapentadecane (14)

A solution of $18(0.71 \mathrm{~g}, 1.96 \mathrm{mmol})$ in anhydrous THF $(6 \mathrm{~mL})$ was added dropwise with stirring to a suspension of $\mathrm{NaH}$ (60\% dispersion in mineral oil, $0.43 \mathrm{~g}, 10.8 \mathrm{mmol})$ in anhydrous THF $(10 \mathrm{~mL})$. After $10 \mathrm{~min}$, a solution of $\mathrm{Bu}_{4} \mathrm{NI}(0.02 \mathrm{~g}, 0.05 \mathrm{mmol})$ in THF $(1 \mathrm{~mL})$ was added followed by a solution of iodomethane $(0.50 \mathrm{~mL}, 1.14 \mathrm{~g}, 8.0 \mathrm{mmol})$ in THF $(5 \mathrm{~mL})$. The reaction mixture was stirred at room temperature under inert atmosphere (argon) for $14 \mathrm{~h}$, and then diethyl ether $(20 \mathrm{~mL})$ was added. The reaction mixture was cooled to $0^{\circ} \mathrm{C}$ and quenched by slow dropwise addition of water, until the evolution of hydrogen stopped. The mixture was diluted with water $(20 \mathrm{~mL})$, the organic layer was separated, and the aqueous layer was extracted with diethyl ether $(3 \times 20 \mathrm{~mL})$. The combined organic extracts were dried over $\mathrm{Na}_{2} \mathrm{SO}_{4}$. The solvent was removed under reduced pressure, and title compound was isolated by column chromatography $\left(\mathrm{SiO}_{2}\right.$, eluent PE:EtOAc, 40:1). Colorless oil $(0.71 \mathrm{~g}, 96 \%) . R_{f}=0.45$ (PE:EtOAc, $\left.10: 1\right) .[\alpha]_{\mathrm{D}}{ }^{20}=+14.5\left(c 0.84, \mathrm{CH}_{2} \mathrm{Cl}_{2}\right)$. IR (neat): $v=1464,1380,1255,1147,1096,1043,836,776 \mathrm{~cm}^{-1} .{ }^{1} \mathrm{H} \mathrm{NMR}\left(400 \mathrm{MHz} \mathrm{CDCl}_{3}\right)$ : $\delta=4.68(\mathrm{~d}, J=6.8 \mathrm{~Hz}, 1 \mathrm{H}), 4.65(\mathrm{~d}, J=6.8 \mathrm{~Hz}, 1 \mathrm{H}), 3.75-3.58(\mathrm{~m}, 3 \mathrm{H}), 3.49-3.41(\mathrm{~m}, 1 \mathrm{H})$, $3.39(\mathrm{~s}, 3 \mathrm{H}), 3.32(\mathrm{~s}, 3 \mathrm{H}), 1.79-1.66(\mathrm{~m}, 1 \mathrm{H}), 1.65-1.27(\mathrm{~m}, 9 \mathrm{H}), 1.16(\mathrm{ddd}, J=13.8,8.2,5.3 \mathrm{~Hz}$, $1 \mathrm{H}), 0.97-0.83(\mathrm{~m}, 15 \mathrm{H}), 0.04(\mathrm{~s}, 6 \mathrm{H}) .{ }^{13} \mathrm{C} \mathrm{NMR}\left(100.6 \mathrm{MHz}, \mathrm{CDCl}_{3}\right): \delta=95.94,75.53,75.05$, 61.27, 55.89, 55.60, 42.01, 40.40, 40.36, 37.54, 26.29, 25.95 (3C), 20.03, 18.30, 18.25, 14.28, -5.28, -5.32. HRMS (ESI) calcd. for $\mathrm{C}_{20} \mathrm{H}_{44} \mathrm{O}_{4} \mathrm{SiNa}^{+}[\mathrm{M}+\mathrm{Na}]^{+}$399.2901, found $\mathrm{m} / z$ 399.2902.

\subsubsection{0. (3R,5S,7S)-5-Methoxy-7-(methoxymethoxy)-3-methyldecan-1-ol (19)}

PPTS $(0.021 \mathrm{~g}, 0.08 \mathrm{mmol})$ was added to a solution of silyl ether $14(3.080 \mathrm{~g}, 8.20 \mathrm{mmol})$ in methanol $(50 \mathrm{~mL})$ and the reaction mixture was kept at room temperature for $15 \mathrm{~h}$. Triethylamine $(0.060 \mathrm{~mL}, 0.044 \mathrm{~g}, 0.44 \mathrm{mmol})$ was added, the solvent was removed under reduced pressure, and the residue was purified by column chromatography $\left(\mathrm{SiO}_{2}\right.$, 
PE:EtOAc, 7:1). Colorless oil (2.10 g, 98\%). $R_{f}=0.46$ (PE:EtOAc, 2:1). $[\alpha]_{\mathrm{D}}{ }^{20}=+15.5(c$ 0.84, $\left.\mathrm{CH}_{2} \mathrm{Cl}_{2}\right)$. IR (neat): $v=3442,1463,1379,1144,1094,1042 \mathrm{~cm}^{-1} .{ }^{1} \mathrm{H}$ NMR $(400 \mathrm{MHz}$, $\left.\mathrm{CDCl}_{3}\right): \delta=4.68(\mathrm{~d}, J=6.8 \mathrm{~Hz}, 1 \mathrm{H}), 4.65(\mathrm{~d}, J=6.8 \mathrm{~Hz}, 1 \mathrm{H}), 3.75-3.61(\mathrm{~m}, 3 \mathrm{H}), 3.47-3.39(\mathrm{~m}$, $1 \mathrm{H}), 3.39(\mathrm{~s}, 3 \mathrm{H}), 3.33(\mathrm{~s}, 3 \mathrm{H}), 1.84-1.29(\mathrm{~m}, 11 \mathrm{H}), 1.19(\mathrm{ddd}, J=13.5,8.1,5.1 \mathrm{~Hz}, 1 \mathrm{H}), 0.95$ $(\mathrm{d}, J=6.7 \mathrm{~Hz}, 3 \mathrm{H}), 0.91(\mathrm{t}, J=7.2 \mathrm{~Hz}, 3 \mathrm{H}) .{ }^{13} \mathrm{C} \mathrm{NMR}\left(100.6 \mathrm{MHz}, \mathrm{CDCl}_{3}\right): \delta=95.81,75.90$, $75.05,60.80,56.13,55.63,41.78,40.20,40.14,37.41,26.20,20.26,18.23,14.24$. HRMS (ESI) calcd. for $\mathrm{C}_{14} \mathrm{H}_{30} \mathrm{O}_{4} \mathrm{Na}^{+}[\mathrm{M}+\mathrm{Na}]^{+}$285.2036, found $m / z 285.2039$.

\subsubsection{1. (3S,5S,7S)-5-Methoxy-7-(methoxymethoxy)-3-methyldecanal (15) [55]}

A solution of DMSO $(0.58 \mathrm{~g}, 7.4 \mathrm{mmol})$ in anhydrous $\mathrm{CH}_{2} \mathrm{Cl}_{2}(8 \mathrm{~mL})$ was added to a solution of $(\mathrm{COCl})_{2}(0.32 \mathrm{~mL}, 0.47 \mathrm{~g}, 3.7 \mathrm{mmol})$ in anhydrous $\mathrm{CH}_{2} \mathrm{Cl}_{2}(7 \mathrm{~mL})$ at $-78{ }^{\circ} \mathrm{C}$ and the reaction mixture was stirred at the same temperature under inert atmosphere (argon) for $25 \mathrm{~min}$. A solution of alcohol $19(0.76 \mathrm{~g}, 2.9 \mathrm{mmol})$ in anhydrous $\mathrm{CH}_{2} \mathrm{Cl}_{2}(8 \mathrm{~mL})$ was added and the reaction mixture was stirred at $-78{ }^{\circ} \mathrm{C}$ for $1 \mathrm{~h}$. Then triethylamine $(2.30 \mathrm{~mL}, 1.68 \mathrm{~g}$, $16.6 \mathrm{mmol}$ ) was added and the mixture was stirred while gradually warming to $0{ }^{\circ} \mathrm{C}$ for $1 \mathrm{~h}$. The reaction mixture was quenched with water $(25 \mathrm{~mL})$, the organic layer was separated, and the aqueous layer was extracted with $\mathrm{CH}_{2} \mathrm{Cl}_{2}(3 \times 20 \mathrm{~mL})$. The combined organic extracts were dried over $\mathrm{Na}_{2} \mathrm{SO}_{4}$. The solvent was removed under reduced pressure, and the title compound was isolated by column chromatography $\left(\mathrm{SiO}_{2}\right.$, eluent PE:EtOAc, 15:1). Colorless oil $(0.71 \mathrm{~g}, 94 \%) . R_{f}=0.48$ (PE:EtOAc, $\left.4: 1\right) .[\alpha]_{\mathrm{D}}{ }^{20}=+9.4\left(c 0.85, \mathrm{CH}_{2} \mathrm{Cl}_{2}\right)$. IR (neat): $v=1725,1463,1380,1143,1091,1038 \mathrm{~cm}^{-1} .{ }^{1} \mathrm{H}$ NMR $\left(400 \mathrm{MHz}, \mathrm{CDCl}_{3}\right): \delta=9.74(\mathrm{t}$, $J=2.1 \mathrm{~Hz}, 1 \mathrm{H}), 4.67(\mathrm{~d}, J=6.8 \mathrm{~Hz}, 1 \mathrm{H}), 4.64(\mathrm{~d}, J=6.8 \mathrm{~Hz}, 1 \mathrm{H}), 3.74-3.63(\mathrm{~m}, 1 \mathrm{H}), 3.48-3.39$ $(\mathrm{m}, 1 \mathrm{H}), 3.38(\mathrm{~s}, 3 \mathrm{H}), 3.32(\mathrm{~s}, 3 \mathrm{H}), 2.47-2.36(\mathrm{~m}, 1 \mathrm{H}), 2.30-2.20(\mathrm{~m}, 2 \mathrm{H}), 1.69-1.19(\mathrm{~m}, 8 \mathrm{H})$, $1.00(\mathrm{~d}, J=6.3 \mathrm{~Hz}, 3 \mathrm{H}), 0.91(\mathrm{t}, J=7.2 \mathrm{~Hz}, 3 \mathrm{H}) .{ }^{13} \mathrm{C} \mathrm{NMR}\left(100.6 \mathrm{MHz}, \mathrm{CDCl}_{3}\right): \delta=202.56$, $95.85,75.46,74.96,55.92,55.62,51.32,41.54,40.02,37.38,24.99,20.27,18.21,14.23$. HRMS (ESI) calcd. for $\mathrm{C}_{14} \mathrm{H}_{28} \mathrm{O}_{4} \mathrm{Na}^{+}[\mathrm{M}+\mathrm{Na}]^{+} 283.1880$, found $m / z 283.1884$.

\section{Conclusions}

We have developed an improved and cost-efficient protocol for multigram preparation of (allyl)tributylstannane 2 , which can be used as a synthetic equivalent of a $\mathrm{C}_{5}$-bipolar synthon in the synthesis of natural compounds. The use of $\mathbf{2}$ in stereoselective transformations was exemplified by highly diastereoselective 1,3-anti-allylation of aldehyde 3, designed en route to the total synthesis of (+)-Neopeltolide. Scandium triflate was revealed as an effective Lewis acid catalyst in this transformation. Addition of water was found to be crucial for adjusting the catalytic activity of scandium triflate and led to greatly improved stereoselectivity. Although stoichiometric amounts of scandium triflate are required to attain high yield of $\mathbf{8}$, this work represent a rare example of the use of functionalized allylstannanes in stereocontrolled allylation of oxysubstituted aldehydes.

Supplementary Materials: The following are available online at https:/ / www.mdpi.com/2073-899 4/13/3/470/s1, copies of ${ }^{1} \mathrm{H},{ }^{13} \mathrm{C}-\mathrm{NMR}$ and HRMS spectra, synthesis of aldehyde 3 .

Author Contributions: Experimental part, formal analysis, characterization of new compounds, U.S.M.; conceptualization and idea of the research, U.S.M. and I.V.M.; methodology, U.S.M. and D.G.K.; investigation, U.S.M., I.V.M., and D.G.K.; writing-original draft preparation, U.S.M.; writing-review and editing, I.V.M. and D.G.K.; supervision, I.V.M. and D.G.K.; project administration, D.G.K.; funding acquisition, D.G.K. All authors have read and agreed to the published version of the manuscript.

Funding: This research was partially funded by Tallinn University of Technology (TalTech, Grant No. B58) and Belarusian Ministry of Education. U.S.M. is grateful to Dora Plus program for financial support of his research stay at Tallinn University of Technology.

Institutional Review Board Statement: Not applicable.

Informed Consent Statement: Not applicable. 
Data Availability Statement: The data presented in this study are available in the article and supplementary material.

Acknowledgments: Firstly: we would like to thank Eugenijus Butkus (Vilnius University, Lithuania) for his kind invitation and giving us the opportunity to report these results in the special issue "Chirality and Symmetry in Stereochemistry". We would like to thank Ivar Järving (Tallinn University of Technology, TalTech) for his help with HRMS measurements. Alexander-Mati Müürisepp (TalTech) is acknowledged for measuring IR spectra. Marina Kudrjašova (TalTech) and Jasper Adamson (KBFI, Tallinn, Estonia) are acknowledged for their help with NMR acquisitions. Ludmila S. Ivashkevich (Research Institute for Physical Chemical Problems of the Belarusian State University, Minsk, Belarus) is acknowledged for PXRD analysis.

Conflicts of Interest: The authors declare no conflict of interest.

\section{References}

1. Yamamoto, Y.; Asao, N. Selective reactions using allylic metals. Chem. Rev. 1993, 93, 2207-2293. [CrossRef]

2. Denmark, S.E.; Fu, J. Catalytic enantioselective addition of allylic organometallic reagents to aldehydes and ketones. Chem. Rev. 2003, 103, 2763-2794. [CrossRef] [PubMed]

3. Yus, M.; González-Gómez, J.C.; Foubelo, F. Catalytic enantioselective allylation of carbonyl compounds and imines. Chem. Rev. 2011, 111, 7774-7854. [CrossRef]

4. Yus, M.; González-Gómez, J.C.; Foubelo, F. Diastereoselective allylation of carbonyl compounds and imines: Application to the synthesis of natural products. Chem. Rev. 2013, 113, 5595-5698. [CrossRef] [PubMed]

5. Fattah, T.A.; Saeed, A. Applications of Keck allylation in the synthesis of natural products. New J. Chem. 2017, 41, 14804-14821. [CrossRef]

6. Evans, D.A.; Rajapakse, H.A.; Stenkamp, D. Asymmetric syntheses of Pectenotoxins-4 and -8, part I: Synthesis of the C1-C19 subunit. Angew. Chem. Int. Ed. 2002, 41, 4569-4573. [CrossRef]

7. Lee, E.; Jeong, E.J.; Kang, E.J.; Sung, L.T.; Hong, S.K. Total synthesis of Pamamycin-607. J. Am. Chem. Soc. 2001, 123, 10131-10132. [CrossRef] [PubMed]

8. Zhao, X.; Kedei, N.; Michalowski, A.; Lewin, N.E.; Keck, G.E.; Blumberg, P.M. Deletion of the C26 methyl substituent from the Bryostatin analogue Merle 23 has negligible impact on its biological profile and potency. ChemBioChem 2018, 19, 1049-1059. [CrossRef]

9. Timothy, N.; Trotter, T.N.; Albury, A.M.M.; Jennings, M.P. Total synthesis of 7-Deoxy-6-O-methylfusarentin featuring a chelationcontrolled 1,3-Reetz-Keck-type allylation. J. Org. Chem. 2012, 77, 7688-7692.

10. Sabitha, G.; Raoa, A.S.; Yadav, J.S. Synthesis of the C1-C25 southern domain of Spirastrellolides B and F. Org. Biomol. Chem. 2013, 11, 7218-7231. [CrossRef]

11. Kim, W.H.; Hong, S.K.; Lim, S.M.; Ju, M.-A.; Jung, S.K.; Kim, Y.W.; Jung, J.H.; Kwon, M.S.; Lee, E. Total synthesis of IKD-8344. Angew. Chem. Int. Ed. 2006, 45, 7072-7075. [CrossRef] [PubMed]

12. Keck, G.E.; Truong, A.P. Synthetic studies on the Bryostatins: preparation of a truncated BC-ring intermediate by pyran annulation. Org. Lett. 2005, 7, 2149-2152. [CrossRef] [PubMed]

13. Joarder, D.D.; Jennings, M.P. Convergent enantioselective syntheses of two potential C25-C40 subunits of (-)-Caylobolide A. Tetrahedron Lett. 2011, 52, 5124-5127.

14. Keck, G.E.; Yu, T.; McLaws, M.D. Enantio- and diastereoselective additions to aldehydes using the bifunctional reagent 2(chloromethyl)-3-(tributylstannyl) propene: application to a synthesis of the C16-C27 segment of Bryostatin 1. J. Org. Chem. 2005, 70, 2543-2550. [CrossRef]

15. Bartolo, N.D.; Read, J.A.; Valentín, E.M.; Woerpel, K.A. Reactions of allylmagnesium reagents with carbonyl compounds and compounds with $\mathrm{C}=\mathrm{N}$ double bonds: Their diastereoselectivities generally cannot be analyzed using the Felkin-Anh and chelation-control models. Chem. Rev. 2020, 120, 1513-1619. [CrossRef]

16. Mengel, A.; Reiser, O. Around and beyond Cram's rule. Chem. Rev. 1999, 99, 1191-1224. [CrossRef]

17. Reetz, M.T. Chelation or non-chelation control in addition reactions of chiral $\alpha$-and $\beta$-alkoxy carbonyl compounds. Angew. Chem. Int. Ed. Engl. 1984, 23, 556-569. [CrossRef]

18. Cherest, M.; Felkin, H.; Prudent, N. Torsional strain involving partial bonds. The stereochemistry of the lithium aluminium hydride reduction of some simple open-chain ketones. Tetrahedron Lett. 1968, 9, 2199-2204. [CrossRef]

19. Cherest, M.; Felkin, H. Torsional strain involving partial bonds. The steric course of the reaction between allyl magnesium bromide and 4-t-butyl-cyclohexanone. Tetrahedron Lett. 1968, 9, 2205-2208. [CrossRef]

20. Anh, N.T.; Eisenstein, O. Induction asymetrique 1-2: Comparaison ab initio des modeles de Cram, de Cornforth, de Karabatsos et de Felkin. Tetrahedron Lett. 1976, 17, 155-158. [CrossRef]

21. Anh, N.T. Regio- and stereo-selectivities in some nucleophilic reactions. Top. Curr. Chem. 1980, 88, 145-162.

22. Cornforth, J.W.; Cornforth, R.H.; Mathew, K.K. A general stereoselective synthesis of olefins. J. Chem. Soc. 1959, 1, 112-127. [CrossRef] 
23. Evans, D.A.; Siska, S.J.; Cee, V.J. Resurrecting the Cornforth model for carbonyl addition: Studies on the origin of 1,2-asymmetric induction in enolate additions to heteroatom-substituted aldehydes. Angew. Chem. Int. Ed. 2003, 42, 1761-1765. [CrossRef]

24. Cee, V.J.; Cramer, C.J.; Evans, D.A. Theoretical investigation of enolborane addition to $\alpha$-heteroatom-substituted aldehydes. Relevance of the Cornforth and polar Felkin-Anh models for asymmetric induction. J. Am. Chem. Soc. 2006, 128, $2920-2930$. [CrossRef]

25. Cram, D.J.; Elhafez, F.A.A. Studies in stereochemistry. X. The rule of "steric control of asymmetric induction" in the syntheses of acyclic systems. J. Am. Chem. Soc. 1952, 74, 5828-5835. [CrossRef]

26. Cram, D.J.; Kopecky, K.R. Studies in stereochemistry. XXX. Models for steric control of asymmetric induction. J. Am. Chem. Soc. 1959, 81, 2748-2755. [CrossRef]

27. Leitereg, T.J.; Cram, D.J. Studies in stereochemistry. XXXVIII. Open-chain vs. cyclic models for 1,3-asymmetric induction in addition reactions. J. Am. Chem. Soc. 1968, 90, 4019-4026. [CrossRef]

28. Reetz, M.T.; Jung, A. 1,3-Asymmetric induction in addition reactions of chiral $\beta$-alkoxy aldehydes: Efficient chelation control via Lewis acidic titanium reagents. J. Am. Chem. Soc. 1983, 105, 4833-4835. [CrossRef]

29. Reetz, M.T.; Kesseler, K.; Jung, A. Concerning the role of Lewis acids in chelation controlled addition to chiral alkoxy aldehydes. Tetrahedron Lett. 1984, 25, 729-732. [CrossRef]

30. Reetz, M.T. Structural, mechanistic, and theoretical aspects of chelation-controlled carbonyl addition reactions. Acc. Chem. Res. 1993, 26, 462-468. [CrossRef]

31. Keck, G.E.; Castellino, S. On the origins of stereoselectivity in chelation controlled nucleophilic additions to $\beta$-alkoxy aldehydes: Solution structures of Lewis acid complexes via NMR spectroscopy. J. Am. Chem. Soc. 1986, 108, 3847-3849. [CrossRef]

32. Keck, G.E.; Castellino, S.; Wiley, M.R. Dramatic effects of oxygen substituents on 1,3-asymmetric induction in additions of allyltriphenylstannane to $\beta$-alkoxy aldehydes: A chemical and spectroscopic investigation. J. Org. Chem. 1986, 51, 5478-5480. [CrossRef]

33. Keck, G.E.; Boden, E.P.; Wiley, M.R. Total synthesis of (+)-Colletodiol: New methodology for the synthesis of macrolactones. J. Org. Chem. 1989, 54, 896-906. [CrossRef]

34. Keck, G.E.; Abbott, D.E.; Wiley, M.R. New allylstannanes for the connective construction of monoprotected vicinal diols. Tetrahedron Lett. 1987, 28, 139-142. [CrossRef]

35. Keck, G.E.; Murry, J.A. Total synthesis of (-)-Colletol. J. Org. Chem. 1991, 56, 6606-6611. [CrossRef]

36. Keck, G.E.; Truong, A.P. Synthetic studies on the Bryostatins: synthetic routes to analogues containing the tricyclic macrolactone core. Org. Lett. 2005, 7, 2153-2156. [CrossRef]

37. Keck, G.E.; Giles, R.L.; Cee, V.J.; Wager, C.A.; Yu, T.; Kraft, M.B. Total synthesis of Epothilones B and D: Stannane equivalents for $\beta$-keto ester dianions. J. Org. Chem. 2008, 73, 9675-9691. [CrossRef] [PubMed]

38. Keck, G.E.; Welch, D.S.; Vivian, P.K. Synthetic studies toward the Bryostatins: a substrate-controlled approach to the A-ring. Org. Lett. 2006, 8, 3667-3670. [CrossRef] [PubMed]

39. Keck, G.E.; Welch, D.S.; Poudel, Y.B. Synthetic studies toward Bryostatin 1: Preparation of a C1-C16 fragment by pyran annulation. Tetrahedron Lett. 2006, 47, 8267-8270. [CrossRef]

40. Tanaka, T.; Murai, Y.; Kishi, T.; Takamura, H.; Kadota, I. Convergent total synthesis of (-)-Dactylolide. Tetrahedron Lett. 2018, 59, 763-766. [CrossRef]

41. Williams, D.R.; Plummer, S.V.; Patnaik, S. Formal synthesis of leucascandrolide A. Angew. Chem. Int. Ed. 2003, 42, 3934-3938. [CrossRef]

42. Williams, D.R.; Patnaik, S.; Plummer, S.V. Leucascandrolide A: a second generation formal synthesis. Org. Lett. 2003, 5, 5035-5038. [CrossRef] [PubMed]

43. Skepper, C.K.; Quach, T.; Molinski, T.F. Total synthesis of Enigmazole A from cinachyrella enigmatica. Bidirectional bond constructions with an ambident 2,4-disubstituted oxazole synthon. J. Am. Chem. Soc. 2010, 132, 10286-10292. [CrossRef] [PubMed]

44. Ahlers, A.; Haro, T.; Gabor, B.; Fürstner, A. Concise total synthesis of Enigmazole A. Angew. Chem. Int. Ed. 2016, 55, 1406-1411. [CrossRef]

45. El-Gaber, M.K.A.; Yasuda, S.; Iida, E.; Mukai, C. Enantioselective total synthesis of (+)-Sieboldine A. Org. Lett. 2017, 19, 320-323. [CrossRef] [PubMed]

46. Smith, A.B.; Zhu, W.; Shirakami, S.; Sfouggatakis, C.; Doughty, V.A.; Bennett, C.S.; Sakamoto, Y. Total synthesis of (+)-Spongistatin 1. An effective second-generation construction of an advanced EF wittig salt, fragment union, and final elaboration. Org. Lett. 2003, 5, 761-764. [CrossRef] [PubMed]

47. Lu, Y.; Woo, S.K.; Krische, M.J. Total synthesis of Bryostatin 7 via C-C bond-forming hydrogenation. J. Am. Chem. Soc. 2011, 133, 13876-13879. [CrossRef]

48. Sanchez, C.C.; Keck, G.E. Total synthesis of (+)-Dactylolide. Org. Lett. 2005, 7, 3053-3056. [CrossRef]

49. Cai, X.; Liang, W.; Dai, M. Total syntheses via cyclopropanols. Tetrahedron 2019, 75, 193-208. [CrossRef]

50. Haym, I.; Brimble, M.A. The Kulinkovich hydroxycyclopropanation reaction in natural product synthesis. Org. Biomol. Chem. 2012, 10, 7649-7665. [CrossRef] [PubMed] 
51. Elek, G.Z.; Koppel, K.; Zubrytski, D.M.; Konrad, N.; Järving, I.; Lopp, M.; Kananovich, D.G. Divergent access to histone deacetylase inhibitory cyclopeptides via a late-stage cyclopropane ring cleavage strategy. Short synthesis of Chlamydocin. Org. Lett. 2019, 21, 8473-8478. [CrossRef]

52. Zubrytski, D.M.; Kananovich, D.G.; Matiushenkov, E.A. Preparation of stereochemically pure E- and Z-alkenoic acids and their methyl esters from bicyclo[n.1.0]alkan-1-ols. Application in the synthesis of insect pheromones. Russ. J. Org. Chem. 2017, 53, 813-823. [CrossRef]

53. Mineeva, I.V.; Kulinkovich, O.G. Preparation of 3-bromomethyl-3-butenal diethylacetal and its conversion into isoprenoid aldehydes derivatives. Russ. J. Org. Chem. 2009, 45, 1623-1632. [CrossRef]

54. Mineyeva, I.V.; Kulinkovich, O.G. Methyl 3-bromomethyl-3-butenoate as an isopentane building block for the stereoselective preparation of (S)-4-methyl-3,6-dihydro-2H-pyran-2-carbaldehyde and (+)-faranal. Tetrahedron Lett. 2010, 51, 1836-1839. [CrossRef]

55. Mineeva, I.V. New approach to the synthesis of macrocyclic core of cytotoxic lactone (+)-Neopeltolide. Synthesis of C7-C14 segment basing on cyclopropanol intermediates. Russ. J. Org. Chem. 2015, 51, 1061-1070. [CrossRef]

56. Masyuk, V.S.; Mineeva, I.V. Synthesis of phenyl analog of retinoic acid methyl ester proceeding from 3-(bromomethyl)but-3-enal diethylacetal. Russ. J. Org. Chem. 2017, 53, 1642-1650. [CrossRef]

57. Masyuk, V.S.; Mineeva, I.V. Synthesis of $\beta$-(2,2-diethoxyethyl)-substituted (allyl)tributylstannane and its application to asymmetric allylation. Russ. J. Org. Chem. 2016, 52, 178-185. [CrossRef]

58. Kulinkovich, O.G. The chemistry of cyclopropanols. Chem. Rev. 2003, 103, 2597-2632. [CrossRef] [PubMed]

59. McDonald, T.R.; Mills, L.R.; West, M.S.; Rousseaux, S.A.L. Selective carbon-carbon bond cleavage of cyclopropanols. Chem. Rev. 2021, 121, 3-79. [CrossRef]

60. Cha, J.K.; Kulinkovich, O.G. The Kulinkovich cyclopropanation of carboxylic acid derivatives. Org. React. 2012, 77, 1-160.

61. Kozyrkov, Y.Y.; Kulinkovich, O.G. A simple and efficient conversion of tertiary cyclopropanols to 2-substituted allyl halides. Synlett 2002, 3, 443-446. [CrossRef]

62. Kulinkovich, O.G.; Kozyrkov, Y.Y.; Bekish, A.V.; Matiushenkov, E.A.; Lysenko, I.L. A convenient way for the conversion of carboxylic esters into 2-substituted allyl halides. Synthesis 2005, 10, 1713-1717. [CrossRef]

63. Kananovich, D.G.; Hurski, A.L.; Kulinkovich, O.G. A highly stereoselective transformation of carboxylic esters to trisubstituted olefins via cationic cyclopropyl-allyl rearrangement of sulfonates of cis-1,2-disubstituted cyclopropanols. Tetrahedron Lett. 2007, 48, 8424-8429. [CrossRef]

64. Wright, A.E.; Botelho, J.C.; Guzman, E.; Harmody, D.; Linley, P.; McCarthy, P.J.; Pitts, T.P.; Pomponi, S.A.; Reed, J.K. Neopeltolide, a macrolide from a lithistid sponge of the family neopeltidae. J. Nat. Prod. 2007, 70, 412-416. [CrossRef]

65. Bai, Y.; Dai, M. Strategies and methods for the synthesis of anticancer natural product Neopeltolide and its analogs. Curr. Org. Chem. 2015, 19, 871-885. [CrossRef] [PubMed]

66. Fuwa, H. Contemporary strategies for the synthesis of tetrahydropyran derivatives: Application to total synthesis of Neopeltolide, a marine macrolide natural product. Mar. Drugs 2016, 14, 65. [CrossRef] [PubMed]

67. Keck, G.E.; Tarbet, K.H.; Geraci, L.S. Catalytic asymmetric allylation of aldehydes. J. Am. Chem. Soc. 1993, 115, 8467-8468. [CrossRef]

68. Keck, G.E.; Geraci, L.S. Catalytic asymmetric allylation (CAA) reactions. II. A new enantioselective allylation procedure. Tetrahedron Lett. 1993, 34, 7827-7828. [CrossRef]

69. Keck, G.E.; Krishnamurthy, D.; Grier, M.C. Catalytic asymmetric allylation reactions. 3. Extension to methallylstannane, comparison of procedures, and observation of a nonlinear effect. J. Org. Chem. 1993, 58, 6543-6544. [CrossRef]

70. Wender, P.A.; Verma, V.A. The design, synthesis, and evaluation of C7 diversified Bryostatin analogs reveals a hot spot for PKC affinity. Org. Lett. 2008, 10, 3331-3334. [CrossRef]

71. Yu, C.-M.; Choi, H.-S.; Yoon, S.-K.; Jung, W.-H. Effects of subjoin Lewis Acid on the catalytic asymmetric allylic transfer reactions of aldehydes promoted by BINOL-Ti (IV) complex. Synlett 1997, 8, 889-890. [CrossRef]

72. Banerjee, B. Sc(OTf) $)_{3}$ catalyzed carbon-carbon and carbon-heteroatom bond forming reactions: A review. Arkivoc 2017, 2017, 1-25 [CrossRef]

73. Pellissier, H. Recent developments in enantioselective scandium-catalyzed transformations. Coord. Chem. Rev. 2016, 313, 1-37. [CrossRef]

74. Kobayashi, S.; Sugiura, M.; Kitagawa, H.; Lam, W.W.-L. Rare-earth metal triflates in organic synthesis. Chem. Rev. 2002, 102, 2227-2302. [CrossRef] [PubMed]

75. Kobayashi, S. Scandium triflate in organic synthesis. Eur. J. Org. Chem. 1999, 1999, 15-27. [CrossRef]

76. Rossini, A.J.; Hildebrand, M.P.; Hazendonk, P.A.; Schurko, R.W. Multinuclear solid-state NMR studies of polymer-supported scandium triflate catalysts. J. Phys. Chem. C 2014, 118, 22649-22662. [CrossRef]

77. Kimbrough, T.J.; Roethle, P.A.; Mayer, P.; Trauner, D. Total synthesis of Coralloidolides A, B, C, and E. Angew. Chem. Int. Ed. 2010, 49, 2619-2621. [CrossRef]

78. Bai, S.; Liao, Y.; Lin, L.; Luo, W.; Liu, X.; Feng, X. N, N'-Dioxide-scandium (III)-catalyzed asymmetric aza-Friedel-Crafts reaction of sesamol with aldimines. J. Org. Chem. 2014, 79, 10662-10668. [CrossRef]

79. Kobayashi, S.; Tsuchiya, T.; Komoto, I.; Matsuo, J. Scandium perfluoroalkanesulfonate-catalyzed Diels-Alder reactions in an organic solvent. J. Organomet. Chem. 2001, 624, 392-394. [CrossRef] 
80. Rychnovsky, S.D.; Skalitzky, D.J. Stereochemistry of alternating polyol chains: ${ }^{13} \mathrm{C}$ NMR analysis of 1,3-diol acetonides. Tetrahedron Lett. 1990, 31, 945-948. [CrossRef]

81. Evans, D.A.; Rieger, D.L.; Gage, J.R. ${ }^{13} \mathrm{C}$ NMR chemical shift correlations in 1,3-diol acetonides. Implications for the stereochemical assignment of propionate-derived polyols. Tetrahedron Lett. 1990, 31, 7099-7100. [CrossRef]

82. Cambridge Structural Database. Available online: https:/ / www.ccdc.cam.ac.uk/structures/ (accessed on 18 February 2021).

83. Limbach, M.; Dalai, S.; de Meijere, A. Cyclopropyl building blocks for organic synthesis, Part 100. Advanced syntheses of cyclopropylideneacetates-versatile multifunctional building blocks for organic synthesis. Adv. Synth. Catal. 2004, 346, 760-766. [CrossRef]

84. Mineeva, I.V.; Kulinkovich, O.G. Synthesis of methyl 3-bromomethylbut-3-enoate and its reactions with aldehydes and tributylchlorostannane in the presence of zinc. Russ. J. Org. Chem. 2008, 44, 1261-1266. [CrossRef] 